\title{
SABER ECOLÓGICO TRADICIONAL DA COMUNIDADE RURAL LINHA CRICIUMAL, CÂNDIDO DE ABREU - PR: PRÁTICAS E REPRESENTAÇÕES DA FERTILIDADE DAS TERRAS
}

\author{
Traditional ecological knowledge of rural community linha \\ Criciumal, Cândido de Abreu - PR: practices and representations \\ of the fertility of lands
}
Conocimiento ecológico tradicional de la comunidad rural linha Criciumal, Cândido de Abreu - PR: prácticas y representaciones de la fertilidad de las tierras

\section{Juliano Strachulski}

Mestrado em Geografia pela Universidade Estadual de Ponta Grossa (UEPG). Doutorando em Geografia (UEPG).

Av. General Carlos Cavalcanti, 4748 - Uvaranas, Ponta Grossa - PR, 84030-900, Brasil.

E.mail: julianomundogeo@gmail.com

\section{Nicolas Floriani}

Doutorado em Meio Ambiente e Desenvolvimento pela Universidade Federal do Paraná (UFPR). Prof. Adjunto da Universidade Estadual de Ponta Grossa (UEPG). Membro permanente do Programa de Pós-graduação em Geografia (UEPG).

Av. General Carlos Cavalcanti, 4748 - Uvaranas, Ponta Grossa - PR, 84030-900, Brasil.

E.mail:florianico@gmail.com

\section{RESUMO}

Este texto baseia-se em resultados de trabalho de dissertação de mestrado e se inscreve numa perspectiva paradigmática da geografia regional e antropologia do lugar como recursos epistemológicos emergentes. A interpretação do conhecimento ecológico local dos agricultores de Linha Criciumal (Cândido de Abreu - PR) figura nesse contexto reflexivo como construção social de natureza baseada em saberes-fazeres, transmitidos e compartilhados pela comunidade, imersos em uma realidade regional cotidianamente vivida. Para tanto, a metodologia embasa-se no processo dialógico interdisciplinar das ciências naturais (pedologia, botânica e ecologia) com as ciências humanas e destas com os conhecimentos baseados-no-lugar. Destarte, permitiu-se entender a relação dos agricultores com a paisagem local, caracterizada pelo sistema de práticas materiais e imateriais, que incide sobre os elementos e processos edáficos (pedológicos e agroecológicos) desta paisagem, alicerçando a representação coletiva da fertilidade das terras. Assim, foi possível compreender a estrutura do sistema de classificação vernacular acerca da qualidade das terras (atributos físicos, químicos e biológicos) da paisagem agrícola da comunidade, bem como a classificação local das plantas indicadoras de sua qualidade. 
Palavras-chave: Conhecimento ecológico, Paisagem, Imaginário de fertilidade, Solos, Plantas indicadoras.

\section{ABSTRACT}

This text is based on results of dissertation work and is part of a paradigmatic perspective of regional geography and anthropology of place as emerging epistemological resources. The interpretation of local ecological knowledge of farmers of Criciumal Line (Cândido de Abreu-PR) figure in this reflective context as social construction of nature based on knowledge, transmitted and shared by the community, immersed in a regional reality daily lived. Therefore, the methodology is based in interdisciplinary dialogical process of natural science (pedology, botany and ecology) with the humanities and of these with the knowledge based-in-place. Thus, allowed if understand the relationship of farmers with the local landscape, characterized by the system of material and immaterial practices, which focuses on elements and processes edaphic (pedological and agroecological), basing collective representation of fertility of lands. So, it was possible to understand the structure of system of classification vernacular about quality of lands (physical, chemical and biological attributes) of the agricultural landscape of community, as well as the local classification of plants indicative of its quality.

Keywords: Ecological knowledge, Landscape, Imaginary of fertility, Soil, Indicator plants.

\section{RESUMEN}

Este texto se basa en los resultados del trabajo de disertación de maestría y es parte de una perspectiva paradigmática de la geografía y la antropología del lugar como recursos epistemológicos emergentes. La interpretación del conocimiento ecológico local de los agricultores de Linha Criciumal (Cândido de Abreu - PR) figura en este contexto reflexivo como construcción social de naturaleza basada en saberes y haceres, transmitidos y compartidos por la comunidad, inmersos en una realidad regional cotidianamente vivida. Por lo tanto, la metodología se basa en el proceso dialógico interdisciplinario de las ciencias naturales (pedología, botánica y ecología) con las humanidades y aquellos que tienen los conocimientos basados-en-el-lugar. Así, se permitió entender la relación de los agricultores con el paisaje local, que se caracteriza por el sistema de prácticas materiales y inmateriales, que se centra en los elementos y procesos edaficos (pedológicos y agroecológicos) de este paisaje, basando la representación colectiva de la fertilidad de la tierra. De esta manera, fue posible comprender la estructura del sistema de clasificación vernacular sobre la calidad de las tierras (atributos físicos, químicos y biológicos ) del paisaje agrícola de la comunidad, así como la clasificación local de plantas indicadoras de su calidad.

Palabras clave: Conocimiento ecológico, Paisaje, Imaginario de la fertilidad, Suelos, Plantas indicadoras. 


\section{INTRODUÇÃO}

O presente texto baseia-se em resultados de trabalho de dissertação de mestrado e se inscreve no contexto de renovação paradigmática da geografia regional (THRIFT, 1996; MCDOWEL, 1996; HAESBAERT, 1999) e da geografia e antropologia do lugar (MATHIEU, 2010; BESSE, 2013), além da antropologia simétrica entre os coletivos humano e nãohumano (LATOUR, 1994; VIVEIROS DE CASTRO, 2002; DESCOLA; INGOLD, 2014).

A interpretação do conhecimento ecológico local da comunidade de agricultores tradicionais de Linha Criciumal (Cândido de Abreu - PR) figura nesse contexto reflexivo como uma construção social da realidade (CORCUFF, 2011) baseado em saberes-fazeres culturais transmitidos e compartilhados entre os habitantes da comunidade imersos em um realidade regional cotidianamente vivida (CLAVAL, 2007; CORREA, 2008; HOLZER, 2008).

O aporte paradigmático hermenêutico (narrativas da relação comunidade-território) e fenomenológico (os objetos intersubjetivados da paisagem) permitiu-nos compreender as práticas culturais materiais (produtivas) e ideais (imaginários) de agricultura e natureza. Nesse sentido, ressurgem e se rediscutem as categorias geográficas e antropossociais de modo de habitar e de viver de uma coletividade (DESCOLA; INGOLD, 2014; MATHIEU, 2010; BESSE, 2013).

Tais recursos epistemológicos, emergentes da discussão pós-estruturalista e pósmoderna, coadunam no reconhecimento da diversidade epistemológica do mundo, traduzida na diversidade cultural (em última instância ontológica), nas emergências cognitivas e na necessidade de uma nova política de natureza a partir da descolonização do pensamento e da ciência por meio da instauração de uma racionalidade ambiental emancipatória (LEFF, 2000).

As comunidades rurais tradicionais possuem geralmente uma identidade com a paisagem que é fruto de práticas sociais e produtivas compatíveis com as particularidades dos ambientes em que estão inseridas. Tais especificidades moldam a cultura local e são moldados por ela, cujos resultados da relação entre sociedade e natureza são expressos na paisagem.

Para realizar a apropriação da natureza local, habitantes de comunidades rurais produzem transformações do seu entorno, assentes em representações sociais de natureza e em valores tradicionais e substanciais (éticos), guiando ações sobre as paisagens ou ecossistemas dos quais dependem para subsistir (TOLEDO; BARRERA-BASSOLS, 2009).

Neste sentido, é importante pensar a paisagem como elemento transformado e transformador das práticas socioterritoriais, sendo marca de ações de grupos humanos e matriz que contempla e exprime aspectos culturais relevantes da sociedade, revela 
características próprias de determinada cultura (comunidade) seus valores, e perspectivas futuras (BERQUE, 1998).

As representações dos elementos naturais por uma comunidade rural, portanto, estão ligadas à forma como esta coletividade se apropria da natureza, a partir do momento que passa modificá-la por meio de suas práticas produtivas.

Resultado do acúmulo de experiências e vivências cotidianas pelos indivíduos em uma dada paisagem, os saberes locais constituem-se em práticas materiais e imateriais (técnicas e crenças) compartilhadas pela comunidade e transmitidas pelos membros mais antigos aos mais jovens ao longo do tempo, integrando o patrimônio cognitivo coletivo acerca do universo natural.

Para tanto, os saberes ecológicos locais necessitam, para seu estudo, de um método que seja capaz de proporcionar uma conectividade e interação das dimensões material e imaterial da realidade socioespacial de uma determinada comunidade rural. Desta forma, se torna possível compreender a lógica que subjaz do processo cognitivo inerente a relação entre os grupos humanos e os ambientes com os quais vem interagindo ao longo do tempo.

Não obstante, a antropologia utiliza-se do recurso semiótico da paisagem para compreender como as práticas produtivas e culturais causam interferências num determinado ambiente. Contudo, desde uma perspectiva simbólica, a antropologia ambiental inverte o lugar das práticas materiais (do sistema econômico) na configuração das representações de natureza, colocando em primeiro plano a influência do sistema simbólico sobre os processos naturais e econômicos (WALDMAN, 2006.).

Corroborando ao acima exposto, apoiado na abordagem interdisciplinar, o enfoque etnoecológico utiliza-se da pluralidade de conceitos e metodologias das ciências sociais e naturais para entender a relação de uma coletividade com o seu ambiente. Portanto, o conceito de paisagem é compartilhado também pela etnoecologia, que busca estudar as maneiras como a natureza é visualizada pelos diferentes grupos humanos (culturas), através de um conjunto de crenças e conhecimentos, e como em termos destas imagens, tais grupos utilizam e/ou manejam os recursos naturais (TOLEDO; BARRERA-BASSOLS, 2009).

Com base nos conceitos acima evidenciados, o presente texto busca compreender a relação dos moradores da comunidade rural de Linha Criciumal, localizada no município de Cândido de Abreu (figura 1), com sua paisagem produtiva, a partir do enfoque etnoecológico e geográfico das práticas locais. Para tanto, buscou-se interpretar cientificamente o saber ecológico tradicional dos agricultores acerca dos processos e dinâmicas edafológicas (fatores bióticos e abióticos) que influenciam na representação da qualidade das terras. 
Figura 1- Mapa de localização da área de estudo. : Mapa mostrando a delimitação do território da comunidade Linha Criciumal, conforme a percepção dos agricultores locais (Cândido de Abreu - PR).

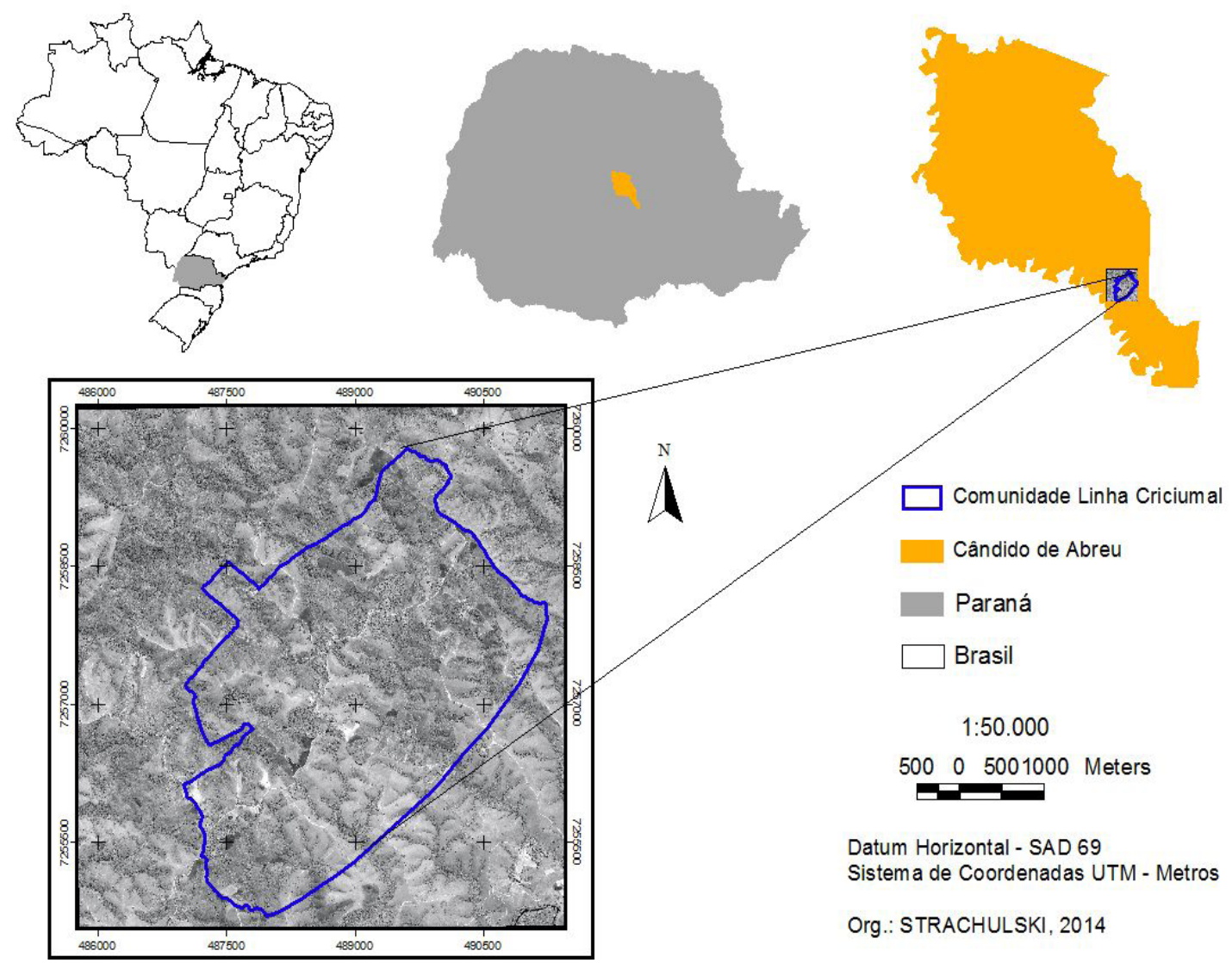

Fonte: STRACHULSKI, 2014.

Assim, na mente dos agricultores de Linha Criciumal não existe um conhecimento acerca dos solos que esteja separado ou sem conexão com outros elementos de sua paisagem produtiva, quase sempre o relacionando com, vegetação, água, relevo, dentre outros. Desta forma, tais saberes possuem um alto grua de complexidade, sendo uma das formas de sua interpretação a Geografia, mediante o conceito de paisagem, aliada as etnociências, que tem por fim compreender o etnoconhecimento, ou seja, o "conhecimento a partir do outro".

\section{PROCEDIMENTOS METODOLÓGICOS}

A metodologia consistiu primeiramente numa aproximação com a comunidade, extraindo informações gerais de conversas informais, a partir da técnica da observação participante (ALBUQUERQUE et al., 2010). Esta técnica foi muito importante, pois permitiu uma maior aproximação com os membros da comunidade, buscando através do convívio cotidiano com estes uma melhor investigação sobre sua relação com a natureza, fazendo parte desta técnica também o acompanhamento à coleta das plantas, e as observações feitas “in situ”. 
Desta maneira, foi possível participar das atividades rotineiras do trabalho agrícola, como a colheita do feijão (figura 2), permitindo compreender os significados e experiências dos agricultores em relação à paisagem e a lógica local de classificação dos tipos de terras e sua relação com as plantas, bem como do tipo de agricultura prática, ou seja, as características da agricultura familiar e o sistema agrário vigente.

\section{Figura 2 - A utilização da técnica da observação participante durante colheita do feijão}

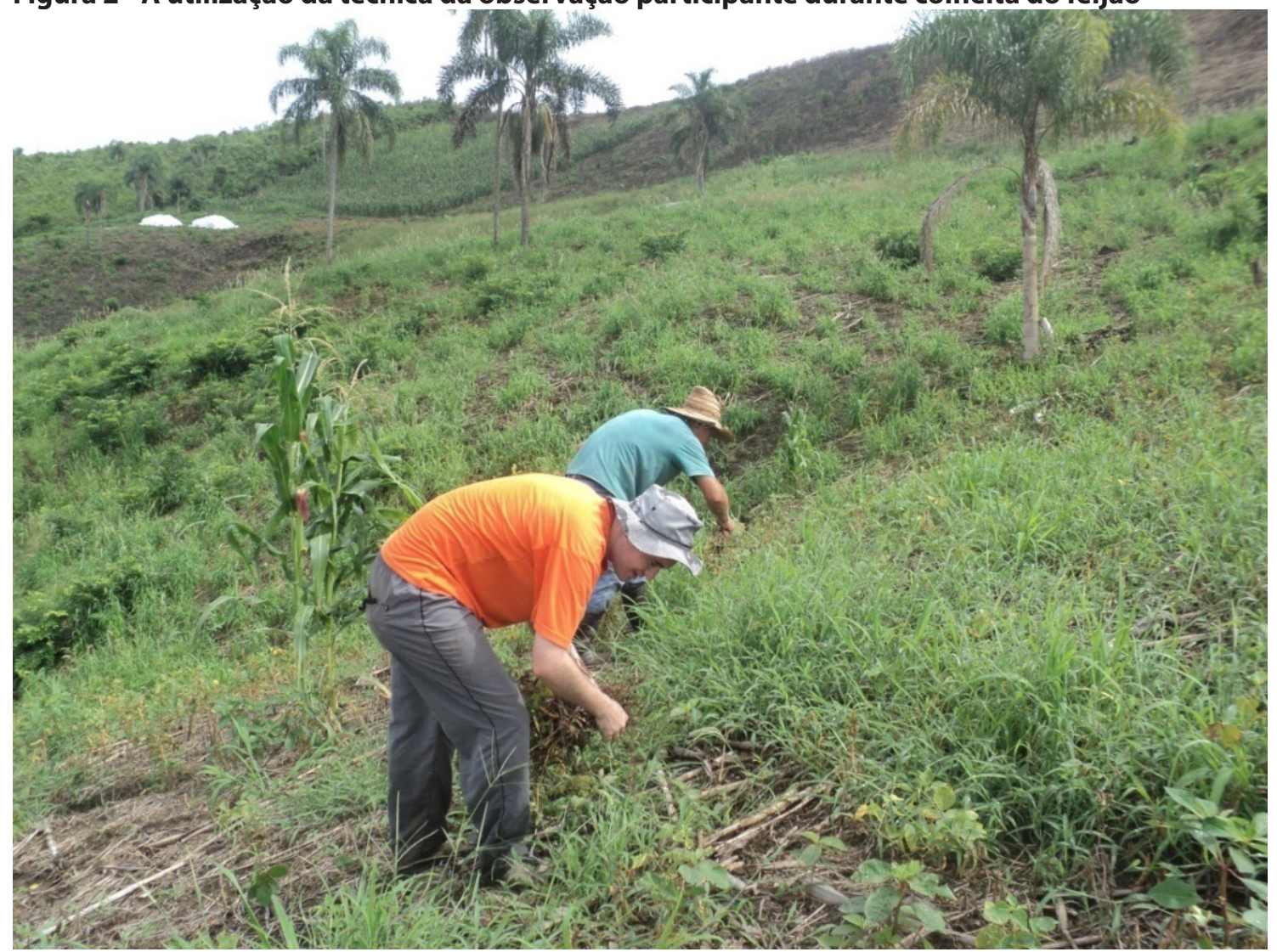

Fonte: STRACHULSKI, 2014 (foto tirada por morador local).

Fonte: STRACHULSK1, 2014 (foto tirada pormorador local).

Legenda: Pesquisador utilizando a técnica de observação participante em momento de troca de dias de serviço na lavoura, durante a colheita de feijão e em companhia dos agricultores locais (6 pessoas participaram da colheita).

Em meio à aproximação com a comunidade, identificou-se um informante-chave, indivíduo cujo conhecimento acerca do meio local (solo e plantas) se destaca em relação aos demais. Tal sujeito foi indicando outros informantes, pessoas que representariam o conhecimento coletivo da comunidade, sendo peças fundamentais na compreensão das práticas produtivas, técnicas, e saberes vernaculares bem como de sua relação com o meio que vivenciam. 
Num universo de pesquisa de 35 famílias, constatou-se que 17 trabalham com atividade agrícola, e destas foi possível realizar a entrevista com 14 informantes, pois os outros potenciais informantes não foram encontrados nos dias em que se realizou o trabalho de campo. Deste modo, os 14 informantes, sendo o (a) chefe-de-família e seu cônjuge e/ou parceiro de trabalho, foram eleitos de acordo aos seguintes critérios: posse legal da terra, agricultura como atividade principal, tempo de residência na comunidade (mínimo de 20 anos), vínculo matrimonial (casado (a)) e relações de trabalho (troca de dias, parceria, arrendamento, reunida, etc.).

Na sequência, através de técnicas de pesquisa participativa como a realização de entrevistas de caráter aberto, semi-estruturado e não estruturado (VERDEJO, 2006; ALBUQUERQUE et al., 2010) possibilitou compreender a diversidade referente às práticas sociais. Para tanto, apoiou-se no método hermenêutico (histórias de vida) e fenomenológico (os objetos intersubjetivados da paisagem), fundamentando-se no processo dialógico interdisciplinar das ciências naturais (pedologia, botânica e ecologia) com as ciências humanas (Geografia e Antropologia) e destas com os conhecimentos baseadosno-lugar, possibilitando compreender as práticas culturais materiais (produtivas) e ideais (imaginários) de agricultura e natureza na paisagem deste território.

Com base nas entrevistas e no método hermenêutico e fenomenológico, utilizando recursos iconográficos (imagem orbital pancromática, de outubro de 2011, com resolução espacial de dois (2) metros) (SEIXAS, 2005), foi possível interpretar os significados das práticas implícitos nos discursos a respeito do conhecimento ecológico local, servindo de auxílio ao mapeamento e classificação das terras pelos agricultores. O trabalho de campo referente às entrevistas e mapeamento participativo das terras ocorreu de 26 de dezembro de 2012 a 11 de janeiro 2013.

A utilização de imagem de satélite mostrou-se a única alternativa de diagnóstico da paisagem e de mapeamento das terras locais, tendo em vista a dificuldade de conseguir a elaboração de desenhos e croquis, representando a comunidade e os tipos de terras, por parte dos agricultores, sendo utilizada de forma proposital.

Portanto, a utilização de imagens como instrumentos de diagnóstico da paisagem e metodologia de reflexão posta aos atores sociais constitui uma ferramenta de visualização e coloca em discussão os pontos de vista dos agricultores e de suas práticas de paisagem, contribuindo para a transformação desta (DEBARBIEUX, 2003).

As imagens associadas à entrevista semi-estruturada permitiram evidenciar os valores, práticas, conhecimentos e imaginário de aptidão (potencialidades e limitações) agrícola das terras da comunidade Linha Criciumal. Neste sentido, foram elaboradas questões abertas 
de acordo aos eixos temáticos abordados: questões relativas à percepção das qualidades das terras; questões relativas à nomenclatura e classificação das terras; e questões referentes aos atributos indicadores de qualidade das terras.

Num segundo momento, mediante a técnica da turnê guiada ou etnocaminhada (ALBUQUERQUE et al., 2010) foi possível coletar as plantas relacionadas aos tipos de terras, que foram levadas até o Herbário da Universidade Estadual de Ponta Grossa (HUPG) para identificação. O trabalho de campo referente à coleta das plantas indicadoras da qualidade das terras ocorreu de 29 a 31 de março de 2013.

Num terceiro momento, após o diagnóstico participativo das terras e coleta das plantas, procedeu-se a abertura e descrição de perfis de solo, coleta de amostras e análise de solos. Os perfis foram abertos de acordo com os tipos de terras encontrados, sendo que foram abertos dois perfis em cada tipo de terra mapeada pelos agricultores. Os trabalhos de campo inerentes a abertura de perfis de solo e a descrição morfológica ocorreram de 19 a 22 de abril de 2013.

Para a descrição morfológica foi utilizada a metodologia de Santos et al. (2005) e coletadas amostras que foram analisadas em relação a parâmetros químicos ( $\mathrm{pH} \mathrm{em} \mathrm{CaCl}_{2}$, Ca, Mg, K, P, C.T.C (Capacidade de troca de cátions), V (Saturação por bases), M (Saturação por alumínio) e C (Carbono) (PAVAN et al., 1992) e granulométricos (areia, silte e argila) (EMBRAPA, 2011). Para realizar a classificação formal de solos adotou-se como referência o Sistema Brasileiro de Classificação de Solos (SANTOS et al., 2013).

Por fim buscou-se a correlação dos saberes vernaculares acerca da qualidade e tipos de terras com as plantas indicadoras e destes com os conhecimentos científicos acerca da qualidade e tipos de solos, observando-se similitudes e contradições, ou seja, confrontandose as formas de saber tradicional e científico.

\section{O SISTEMA AGRÁRIO PRATICADO EM LINHA CRICIUMAL E O CONTEXTO REGIONAL}

Resultado do processo de colonização, a comunidade de Linha Criciumal é uma das muitas que tiveram sua origem a partir da fundação da Colônia Thereza em 1847, na região do rio Ivaí, onde atualmente se encontra, dentre outros, o município de Cândido de Abreu. A comunidade rural Linha Criciumal está localizada no município de Cândido de Abreu, fazendo parte da região histórico-cultural denominada Paraná Tradicional.

A configuração atual do sistema agrário regional e da própria comunidade Linha Criciumal foi tomando forma com a vinda de imigrantes do leste europeu no início do século XX, após o contato com os habitantes nativos, “caboclos", que já habitavam a região. 
Deve-se ressaltar que cada grupo de imigrantes buscou se adaptar a sua realidade, necessidades e capacidade de transformação do meio. Assim, trazem consigo várias características de seus países de origem, "onde muitas continuaram em solo paranaense e outras foram esquecidas ou readaptadas às condições encontradas pelo imigrante na área que foi estabelecido" (HAURESKO; MOTEKA, 2008, p. 15). Portanto, compreende-se que os diversos grupos de imigrantes que adentraram ao território paranaense adotaram modelos agrícolas distintos (WAIBEL, 1949).

Concomitantemente ao modelo agrícola do caboclo, entendido como de roçada e queimada, o modelo agrícola europeu era aos poucos adaptado às condições culturais e ecológicas de cada região paranaense. A agricultura cabocla baseava-se na roçada de vegetação arbórea (capoeira), com sua posterior queimada. Após o curto período de cultivo, a parcela era abandonada a um pousio arbóreo de longa duração (rotação), antes de ser novamente desmatada e apta ao cultivo, o qual poderia durar de dez a várias dezenas de anos (VALVERDE, 1968).

Os modelos agrícolas europeus, por sua vez, eram variados, sendo que em um modelo agrícola havia a integração da lavoura com a pecuária, com rotação de terras de curta duração com 15 a 21 meses de pousio, seguida de quatro a nove meses de cultivo. Outro modelo era o sistema de rotação de culturas (sem pousio) combinada com a criação de gado, e plantio de forrageiras temporárias como nabo e aveia e uso de equipamentos mais pesados como o arado reversor e a grade (WAIBEL 1949; MAZOYER; ROUDART, 2010). Já um terceiro modelo agrícola trazia muitas características do modelo do caboclo.

Ao longo do tempo ocorre uma troca cultural entre caboclos e imigrantes, em que cada um acaba incorporando parcial ou totalmente elementos culturais do outro. Deste modo, os imigrantes foram absorvendo a forma de agricultura dos caboclos, passando a plantar cultivos praticados por estes como o milho, o feijão e a mandioca e realizar a extração da erva-mate e madeira. Porém, os colonos também exerceram influência sobre os caboclos no tocante a técnicas produtivas e práticas sociais.

O contato entre o imigrante e o caboclo nesta região acaba proporcionando novos elementos sociais ao sistema agrário em formação, a partir do surgimento da lógica produtiva camponesa que emerge deste contato. Esta lógica produtiva visa à reprodução do modo de vida camponês e não o lucro. Pois, "O campesinato ou lógica produtiva camponesa procura na terra, muito mais que a renda, mas a concretização de um modo de vida pautado na autonomia do trabalho e na reprodução social delimitada pelos profundos vínculos familiares e comunitários" (PAULINO, 2003, p. 10). 
Os moradores locais são considerados agricultores familiares, apesar da presença de fazendeiros na região, possuindo como componente principal de sua renda a produção de feijão e em segundo plano a produção de milho e venda de animais (suínos, bovinos, ovinos, aves, etc.). Contudo, a renda da casa também pode contar com a aposentadoria de um ente idoso.

A presente comunidade não apresenta uso comum das terras, sendo todas propriedades privadas, cujos terrenos familiares podem ser descontínuos, possuindo várias parcelas tanto próximas quanto distantes da moradia. Já em outros terrenos há estabelecimentos agrícolas com suas parcelas individualizadas, dispostas em uma única propriedade.

Percebe-se que existem várias práticas produtivas tradicionais, como, por exemplo, puxar o milho e o feijão nas costas de cavalos ou do próprio produtor até uma área apropriada para que possa ser debulhado. Além disso, o feijão quando plantado em pequena quantidade é "malhado no cambal", que é técnica tradicional.

Também realizam troca de sementes com seus vizinhos, contudo, poucas são crioulas, predominando qualidades de feijão híbridas. Segundo o agricultor Mariano Crul "A gente troca de semente, porque, senão perde a produção"; realizam capinas com enxada, mesmo que de maneira menos intensa do que antes da modernização da agricultura; utilizam outros instrumentos de agricultura tradicional como o machado, a foice, a cavadeira, e a semeadeira de feijão e milho chamada de "perna-de-grilo" ou matraca.

No modelo agrícola da roçada com queimada são reproduzidos elementos agrícolas europeus, como a inserção de forrageiras (aveia) sob esquemas de rotação aos cultivos consorciados tradicionais (milho-feijão), além dos secundários (mandioca, melancia, etc.).

As relações de trabalho, compreendidas enquanto práticas sociais ligadas à organização do trabalho, também se constituem em elementos tradicionais da agricultura local, como a realização dos mutirões (esporádicos), a “troca de dias" de serviço na lavoura e o plantio em parceria ou "às meia"2.

Por outro lado, as comunidades rurais testemunham um processo de formação socioespacial da região influenciado, a partir da década de 1960, pela implantação do projeto de modernização da agricultura, proporcionando alterações radicais ao sistema

\footnotetext{
Malhar feijão no cambal é uma técnica tradicional de extrair a semente do feijão. Tal técnica consiste em esticar uma lona no chão, colocar as vagens de feijão sobre a lona, e em alguns casos faz-se uma parede com a própria lona em volta das vagens do feijão. Em seguida com uma vara bem flexível a pessoa portadora da vara começa a aplicar golpes nas vagens até que soltem as sementes de feijão, que posteriormente são colhidas e ensacadas.

2 É uma relação de trabalho que se estabelece quando um agricultor oferece a terra a seu vizinho e este entra com o trabalho, ao final da colheita os lucros são divididos ao meio, podendo ser em números de sacas de determinado cultivo ou em dinheiro.
} 
agrário local com evidências de transformação na paisagem regional (TEIXEIRA, 2005).

Atualmente, constata-se a presença de muitas práticas modernas como a utilização, pelos agricultores, de adubos, sementes modificadas geneticamente, forrageiras como a aveia, agrotóxicos (herbicidas e inseticidas), e um dos símbolos da agricultura moderna: a bomba pulverizadora. Também plantam feijão e milho em áreas mais planas, com plantadeiras motomecanizadas e debulham estes, quando plantados em grande quantidade, através de maquinário apropriado.

Esta hibridação de práticas, portanto, reflete-se na paisagem na qual se verificam áreas com práticas produtivas tradicionais (o plantio de feijão, milho e outros cultivos secundários e as capoeiras) imbricadas às áreas com práticas modernas. Destas, destacamse a pecuária mista (corte e leite), que vem se expandindo, tendo início a trinta anos atrás, e a inserção de áreas de reflorestamento com espécies exóticas, como pinus e eucaliptos, há aproximadamente dez anos.

Por outro lado, o componente central do sistema produtivo local, e básico da alimentação, permanece a cultura do feijão, ocupando maior período de tempo e o maior espaço físico dentro do território da comunidade, fazendo convergir grande parte dos recursos (humanos e naturais) no desenvolvimento desta atividade.

Outros sistemas produtivos também se fazem presentes na região, como o cultivo consorciado de milho com feijão, mandioca com melancia, pepino com melancia e melão, dentre outros. A produção destes alimentos, num primeiro momento, visa atender as necessidades alimentares básicas das famílias e suas criações animais, cujos excedentes são comercializados para um atravessador. Portanto, as atividades agrícolas normalmente estão vinculadas à subsistência ou visando o mercado local.

Apesar do avanço do processo de modernização da agricultura e da entrada do capital no campo, para a região da comunidade Linha Criciumal há um fator que gera empecilho a consumação deste processo, pois as características físicas apontadas pelo IPARDES (2007) mostram a presença das maiores declividades da região central do Paraná, além de solos altamente propensos a erosão. Isto impede a utilização de maquinários, na lavoura, por parte dos agricultores familiares.

Tal particularidade regional fez com que as práticas sociais produtivas das comunidades rurais se adaptassem parcialmente ao processo de modernização do campo, o qual provocou tanto mudanças de técnicas na produção agrícola, como das práticas sociais, representando uma diminuição dos momentos de convívio comum. Desta forma, os saberes e práticas 
locais ofereceram relativa resistência à modernização da agricultura, conservando grande parte de seus conhecimentos tradicionais, em especial no que concerne a prática agrícola e o conhecimento dos tipos de terras a ela referentes.

\section{INTERPRETANDO OS SABERES ETNOECOLÓGICOS: CARTOGRAFIA E CLASSIFICAÇÃO VER- NACULARES DA PAISAGEM DA COMUNIDADE LINHA CRICIUMAL}

Na visão de Mendonça (2001, p. 129) uma mudança na forma de pensar e entender a relação entre os grupos humanos com a natureza, mais justa e mais condizente com a realidade, só pode ocorrer a partir de uma abertura ao "diálogo de saberes distintos e sem demover resistências, mas estes acabam por lapidá-lo, pois the proporcionam a experimentação de ousadias e profundo repensar de formulações".

A compreensão da percepção local sobre solos, portanto, passa pela abordagem das etnociências, em especial a etnopedologia que tem como objetivo "estudar as interfaces entre os solos, a espécie humana e os outros componentes dos ecossistemas" (ALVES; MARQUES, 2005, p. 326), possibilitando um diálogo entre conhecimentos científicos e vernaculares a respeito deste tema.

A etnopedologia pode ser entendida como uma das possíveis abordagens do enfoque etnoecológico, o estudo do saber ambiental de populações tradicionais indígenas, que nas últimas décadas tem se dedicado também a estudar os saberes de populações rurais não tradicionais (TOLEDO, 2000). Seu objetivo seria compreender as abordagens tradicionais ou não e sua percepção do solo, sua classificação e de como estas populações o diagnosticam (TOLEDO, 2000).

O espaço rural, cuja particularidade cultural está vinculada a intima relação dos grupos humanos com o meio, ressalta uma cultura arraigada às experiências de seus moradores que evidencia um sentimento de pertencimento e afetividade em relação à terra e cuja expressão se materializa na paisagem. A sociedade rural, assim, é fundada sobre a apropriação e a exploração da terra, considerada como uma realidade carregada de afetividade e pertencimento.

Devido à ligação com a natureza, os agricultores desenvolvem uma herança cognitiva (o corpus de saberes acumulados) que lhes proporciona utilizar os conhecimentos já adquiridos, devido a situações adversas pelas quais eles ou seus antepassados passaram, na resolução ou mitigação de problemas que venham a incidir sobre a lavoura.

Sua manutenção se dá pela transmissão de pais para filhos, contudo, não são apenas acúmulos de conhecimentos transmitidos ao longo das gerações. São processos inacabados 
de produção do conhecimento, cuja capacidade inventiva do ser humano, a partir do contato com uma situação adversa (novo quadro temporal), acaba proporcionando a metamorfose de tais conhecimentos, que são agora a intersecção de visões distintas sobre processos variados ao longo dos tempos.

O lócus aonde estes processos ocorrem são as paisagens que expressam à cultura em suas diversas feições, possuindo um enfoque funcional e outro simbólico, compreendida como uma matriz cultural (BERQUE, 1998). Assim, “[...] as paisagens através de muitos de seus elementos servem como mediação na transmissão de conhecimentos, valores ou símbolos, contribuindo para transferir de uma geração a outra o saber, as crenças, sonhos e atitudes sociais" (CORRÊA, 1995, p. 5).

Para Mendonça (2012) o estudo do conhecimento vernacular, tradicional, atribui grande importância à forma como os grupos humanos compõem, harmonizam e estendem seus laços com a natureza na qual estão incluídos e que lhes proporciona o sustento cultural (material e imaterial), permitindo a sua existência.

"Mede-se a importância dos saberes assim acumulados pelas sociedades camponesas pelos erros que cometem os colonos confrontados a meios cujos ritmos climáticos e seus riscos desconhecem" (CLAVAL, 2007, p. 221). A partir de seu trabalho os agricultores são capazes de identificar, classificar e qualificar as terras nas quais vem trabalhando ao longo de décadas. Este saber se concretiza na prática, pois é construído pelas experiências, que são compostas de tentativa e erro, mas que também inclui processos científicos que acabam marcando as paisagens (WINKLERPRINS; SANDOR, 2003). Para Diegues et al. (1999, p. 30) o conhecimento local é "o conjunto de saberes e saber-fazer a respeito do mundo natural, sobrenatural, transmitido oralmente de geração em geração”.

Para as etnociências, torna-se necessário estabelecer critérios e parâmetros de comparação das estruturas cognitivas que permitam colocar em um relativo nível de similaridade os sistemas cognitivos científicos e vernaculares acerca dos elementos da paisagem. Para alcançar tal comunicabilidade, visou-se a análise científica dos solos da paisagem local para posteriormente compará-los com as estruturas de classificação vernacular.

Compartilhando da temática que se apresenta, a geografia na visão de Mendonça (2001, p. 128) possui uma perspectiva de compreensão da realidade que "se configura, pela característica de multi e interdisciplinaridade e da perspectiva holística na concepção da interação estabelecida entre a sociedade e a natureza [...]”, portanto, também aberta ao diálogo com outras áreas do conhecimento e outras formas de saber. 
Segundo Suertegaray (2002, p. 52) a história de apropriação da natureza e o uso dos recursos naturais pelos grupos humanos, assim, pode ser retratada “[...] através do trabalho e da técnica enquanto instrumentos de produção, acumulação e, por conseqüência, de produção de uma nova natureza [...]", mediante um processo que "ao mesmo tempo em que transforma a natureza, transforma, também, a natureza humana" (SUERTEGARAY, 2004, p. 196). Ou seja, a transformação no ambiente causada pelos grupos humanos também os transforma, sendo que a geografia tem a missão de compreender a relação destes com os recursos naturais e suas formas de conhecimento e gestão.

Desta forma, buscando compreender a relação das pessoas com as terras, foi realizado um mapeamento participativo (figura 3), verificando-se que os agricultores percebem onde estas se localizam, sendo que na paisagem da comunidade há três principais tipos de terras classificadas segundo a visão local: a Terra Branca, a Terra Roxa e a Terra Amarela (figura 4).

Figura 3- Agricultor e pesquisador realizando o mapeamento participativo das terras da comunidade Linha Criciumal

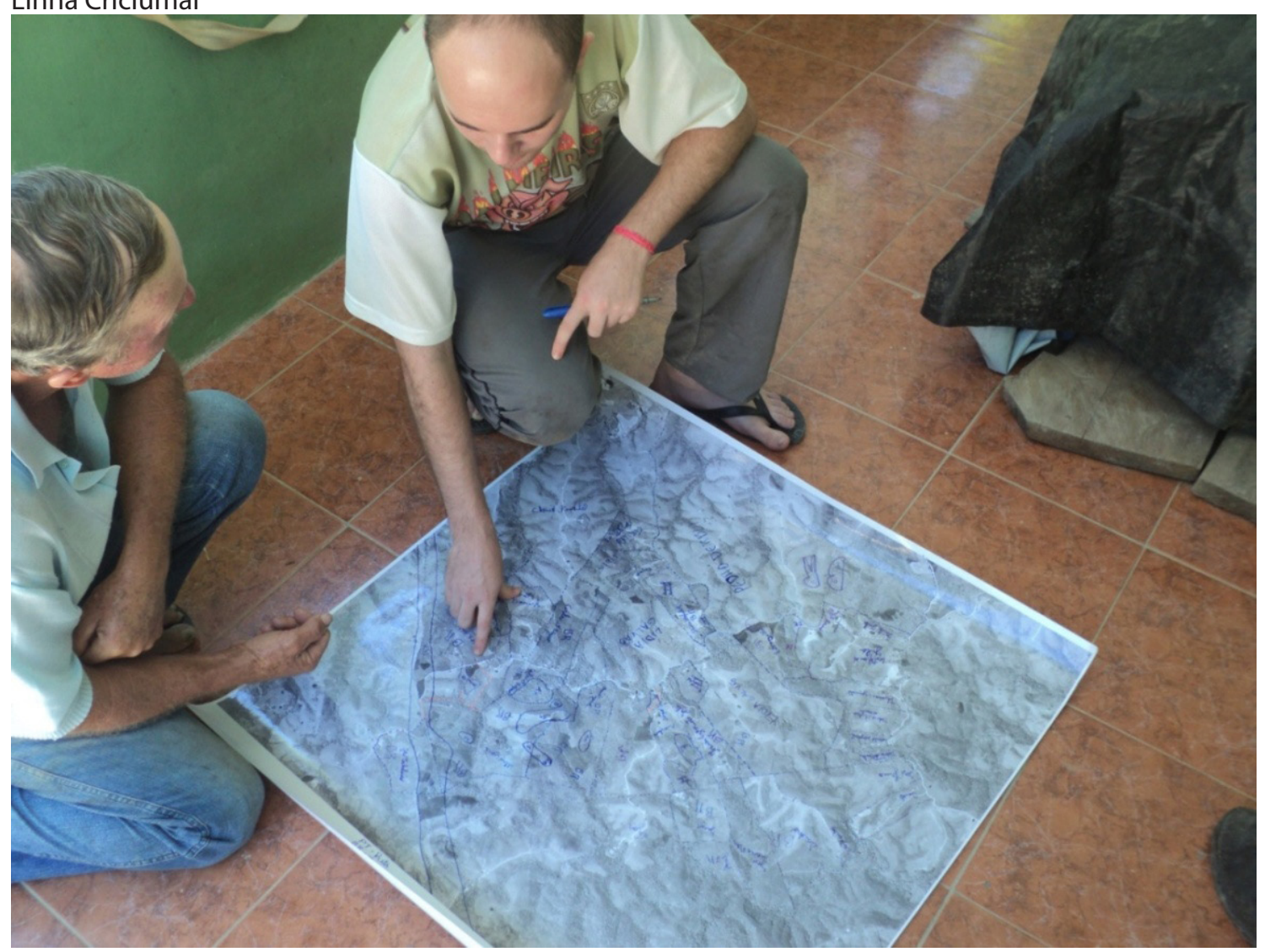

Fonte: STRACHULSKI, 2014 (foto tirada por morador local).

Legenda: Agricultor e pesquisador realizando o mapeamento das terras da comunidade, a partir de uma imagem de satélite impressa e pincel atômico, demarcando os polígonos referentes a cada categoria. 
Figura 4 - Cartografia participativa das terras da comunidade ${ }_{4875000}$ Linha Criciumal

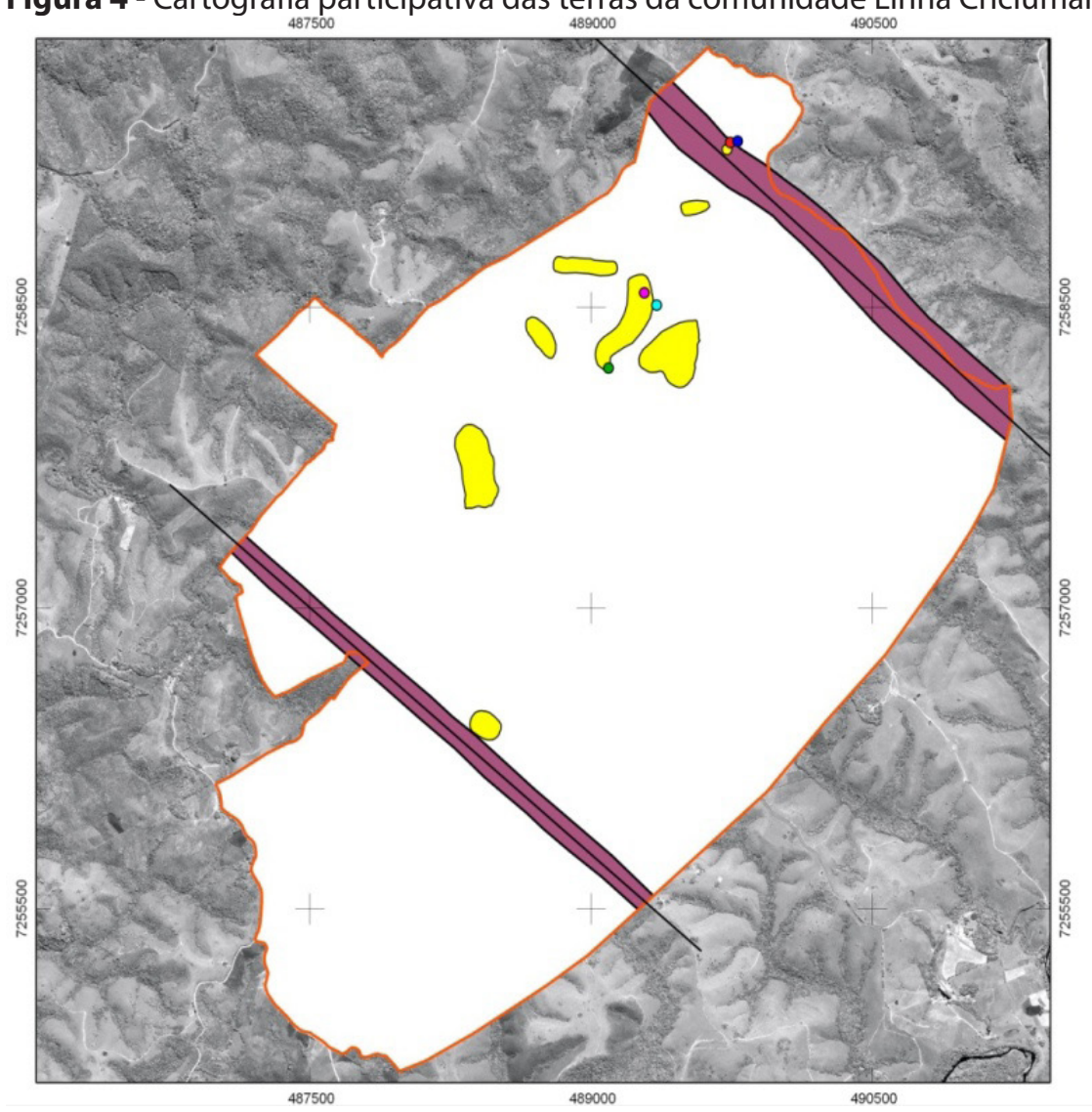

Legenda

$\square$ Comunidade Linha Criciumal

- Dique de diabásio

Perfis de solo descritos

- Perfil 1

- Perfil 2

- Perfil 3

- Perfil 4

- Perfil 5

- Perfil 6

Terras Vernaculares

$\square$ Terra Amarela

$\square$ Terra Branca

$\square$ Terra Roxa

1: 26.000

$\begin{array}{llll}300 \quad 0 & 300 & 600 \text { Metros }\end{array}$

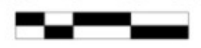

Datum Horizontal - SAD 69

Sistema de Coordenadas UTM -

Metros

Org: STRACHULSKI, 2013

Fonte: STRACHULSKI, 2014.

Legenda: Mapa participativo das terras da comunidade Linha Criciumal, elaborado a partir de entrevistas com os agricultores e digitalizado a partir do programa Quantum GIS 1.6.0 "Capiapó".

A partir da indicação das terras em campo, foram abertos e descritos seis perfis pedológicos, cujos dados das análises físico-químicas permitiram a classificação dos solos de acordo com o Sistema Brasileiro de Classificação de Solos (SANTOS et al., 2013). As classes identificadas foram: Neossolo Litólico Eutrófico fragmentário (Perfil 1), Argissolo Vermelho Eutrófico nitossólico (Perfil 2), Cambissolo Háplico Ta Eutrófico léptico (Perfil 3), Neossolo Litólico Distrófico fragmentário (Perfil 4), Cambissolo Háplico Alítico léptico (Perfil 5) e Cambissolo Háplico Alítico típico (Perfil 6).

Os resultados das análises mostram solos com $\mathrm{pH}$ inferior a 7, que é um valor neutro. Contudo, a maioria apresenta uma baixa C.T.C, exibindo somente um valor acima de $27 \mathrm{cmolc} / \mathrm{dm}^{3}$,culminando numa baixa atividade de argilas ( $\mathrm{Tb}$ ). Em sua maioria, estes solos possuem uma baixa plasticidade e pegajosidade, isto devido apresentarem maior porcentagem de minerais na fração silte, sendo altamente suscetíveis a processos erosivos provocados pela água das chuvas, que costuma carrear sedimentos. O horizonte A mostrou- 
se pouco espesso em todos os perfis em que foi encontrado, dificultando a expansão das raízes dos cultivos e a evolução da planta de feijão e milho.

Os teores de carbono, por sua vez, apresentaram-se todos elevados (acima de $14 \mathrm{~g} /$ $\mathrm{dm}^{3}$ ), indicando solos ricos em matéria orgânica. A saturação por bases apresentou-se abaixo de 50\% em metade dos perfis e na outra metade acima de 50\%, denotando solos distróficos e eutróficos, significando baixa a alta fertilidade.

Após coletados, identificados e descritos os solos serviram de base para a confecção de um diagrama representando uma vertente local e sua paisagem, na qual se verifica a comparação dos tipos de solos e seus respectivos horizontes, bem como a ilustração do formato da vertente, exaltando-se os dados de declividade (figura 5).

Figura 5 - Dados dos perfis e diagrama representando uma vertente local e seus tipos de solos

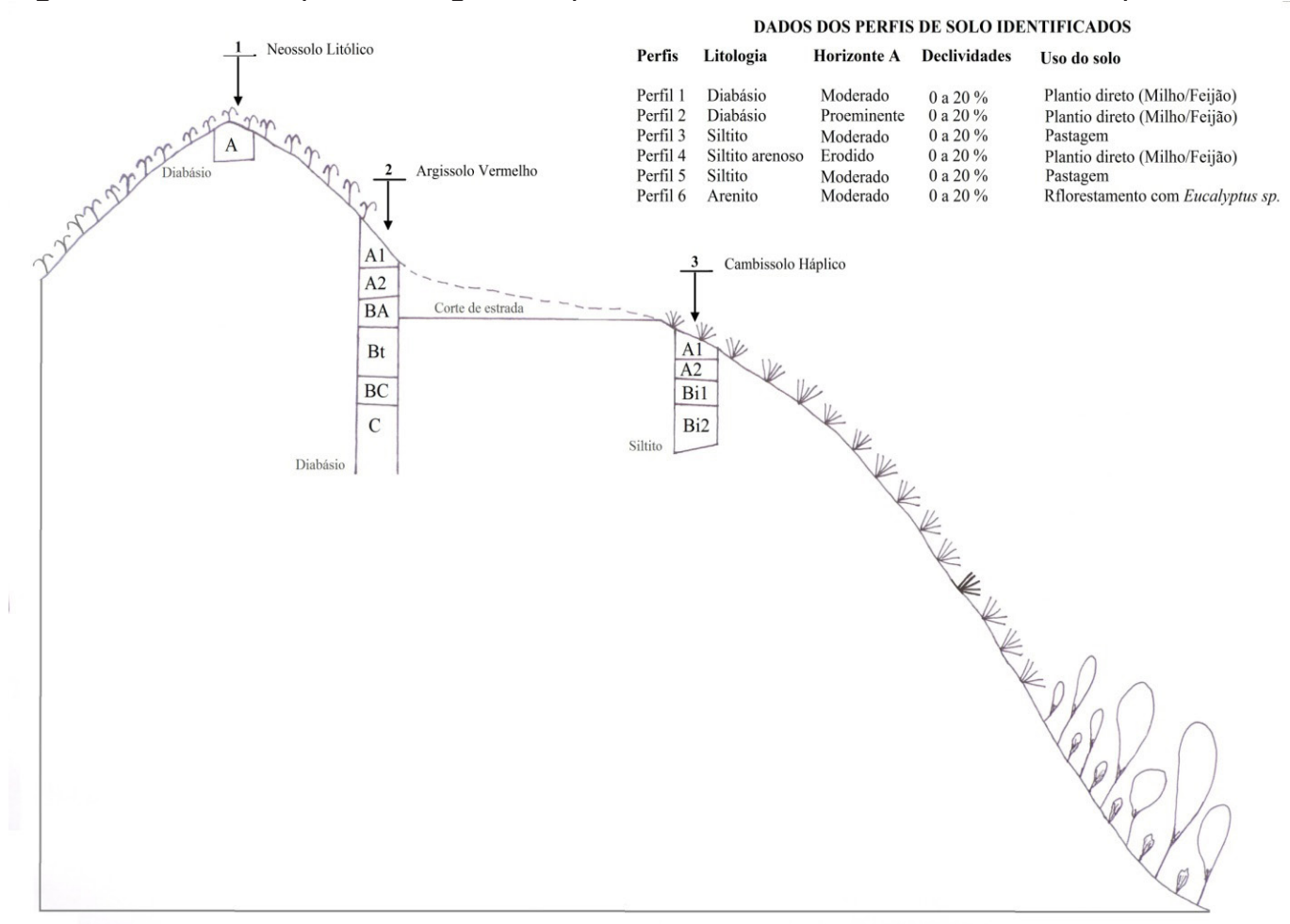

Fonte: STRACHULSKI, 2014.

Legenda: No diagrama se apresenta uma vertente representativa do local, ressaltando a abertura de três perfis de solo e seus horizontes. A tabela acima da vertente representa todos os perfis abertos na Comunidade Linha Criciumal e algumas característica dos locais aonde foram abertos.

Ao que se refere à classificação e qualificação local das terras, o discurso dos agricultores evidenciou uma representação coletiva que aponta um imaginário de fertilidade associado a hierarquização das terras de acordo com a interpretação dos atributos produtivos 
intrínsecos ao solo, a relação solo-planta, a forma de manejo adotada para certos cultivos. Este discurso revelou a existência das categorias terra forte ou terra fraca e terra boa e terra ruim na paisagem local. Tal representação é frequente na fala dos agricultores,

\begin{abstract}
“Terra ruim é a terra branca, é seca, rasa, é mais arenosa na baixada, mais em cima não tem liga, é lavada e pouco gordurosa (...), se fazer um pelote com essa terra ele quebra (racha). Nessa terra nasce mais mato do que feijão (...), tem samambaia e erva-quente, quando chove faz uma camada que fica dura e não afunda quando pisa, ela batuma. Já se fizer um pelote com a terra roxa ele fica firme. A terra roxa é terra boa, depois que chove e você pisa em cima ela afunda, fica fofa. A terra roxa tem massa e da mais produtividade, ela é barrenta, quando chove gruda no pé (quando pisa em cima), nela aparece mais o caruru e o rubin"(Bruno Czerski, agricultor local).
\end{abstract}

Os termos terra boa ou terra ruim aparentam não serem termos próprios dos agricultores locais, para inferir quanto à qualidade de suas terras, sendo mais provável que tenham sofrido a influência de técnicos de órgãos governamentais, como a EMATER local. Os termos que mais comumente aparecem em pesquisas que envolvem estudos etnopedológicos são terra forte e terra fraca (JOHNSON, 1972; BANDEIRA, 1996).

Neste sentido, evidencia-se a existência de duas categorias classificatórias da matriz cognitiva local: uma assente a padrões de agricultura moderna, que classifica as terras em boas e ruins, e outra tradicional, que classifica as terras em fortes e fracas.

Para considerar uma terra boa ou ruim e como elas são, entende-se que há um conjunto de ideias que se articulam, revelando uma lógica classificatória assente a práticas e ideótipos de agricultura moderna e/ou tradicional. Assim, os agricultores falam da importância em manter o solo sempre coberto e citam algumas alternativas: aproveitando a palhada do cultivo anterior; deixam as espontâneas para segurar a terra e como adubo; além da adubação verde, citam a aveia. Segundo o senhor Jorge Crul "aveia segura à umidade, deixa a terra solta e também segura a terra e vira adubo".

São adeptos do plantio direto, pois segundo eles causa menos danos à terra; compreendem os benefícios e os malefícios da queimada, que possibilita a limpeza do terreno e libera nutrientes, mas mata os microorganismos, pois segundo eles "a queimada no momento é bom, porque o feijão dá que é uma beleza, mas pra depois a terra não fica muito boa". Seu conhecimento ecológico local o possibilita compreender ainda que seja necessário realizar a queimada após o corte da capoeira, mas ao mesmo tempo, em relação à capoeirinha falam que não se deve praticar a queimada, pois "tira a força da terra”. Portanto a natureza é vista como riqueza e não somente como recurso (PORTOGONÇALVES, 2004). 
A representação do imaginário de fertilidade e conservação das terras percebida no discurso técnico-agronômico moderno do agricultor tradicional é transformado e adaptado à realidade local, apesar de que poucos agricultores de fato pratiquem essas recomendações. Cabe destacar que há um elemento comum às concepções de fertilidade moderna e tradicional, que é o parâmetro matéria orgânica (PROMIPAC, 2001; FLORIANI, 2007; STRACHULSKI, 2011). Este pode ser compreendido enquanto a "gordura da terra" pelos agricultores locais, e que apesar de ter sido pouco citado enquanto parâmetro de qualidade destas, em praticamente todas as entrevistas aparece como característica das terras.

Ao serem interrogados acerca da importância da terra e o que ela significa, todos relacionam à vida dizendo ser o meio pelo qual proporciona seu sustento e dos outros organismos vivos como a vegetação e outros animais. A seguinte frase dita pelo agricultor Bruno Czerski define bem a importância da terra para os agricultores locais: "A terra é tudo, tudo que vem, vem da terra, terra é sempre terra, da terra tira alimento, material, o pau pra construção. Se não tivesse terra não tinha vida”, nota-se assim a importância do meio em que vivem e sua ligação com ele. Desta forma, vê-se que os camponeses estão intimamente ligados a natureza, pois “[...] o homem é natureza ainda que diferenciado na sua natureza" (SUERTEGARAY, 2003, p. 45).

Os agricultores percebem e classificam os diferentes tipos de terras (Amarela, Branca e Roxa) graças à mudança de cor da litologia (das rochas) e isto se confirma quando informalmente se pergunta a um agricultor quais são os tipos de terras que ele percebe e ele diz: "aqui é terra branca o saibro é branco". Em outra conversa, em meio à observação participante, na colheita do feijão, no chamado troca de dias de serviço, pergunta-se a um agricultor qual era a terra abaixo de uma determinada estrada, e ele diz: "essa é branca, porque essa pedra é diferente daquela lá de cima", se referindo aos fragmentos de rocha oriundos do dique de diabásio que se localiza acima da estrada que foi usada como referência.

No tocante a qualidade das terras, vários são os atributos localmente utilizados para qualificá-las. Na figura 6 é possível visualizar os parâmetros indicadores, elencados de acordo com o número de citações. 
Figura 6 - Indicadores de qualidade das terras, citados pelos agricultores entrevistados na comunidade Linha Criciumal

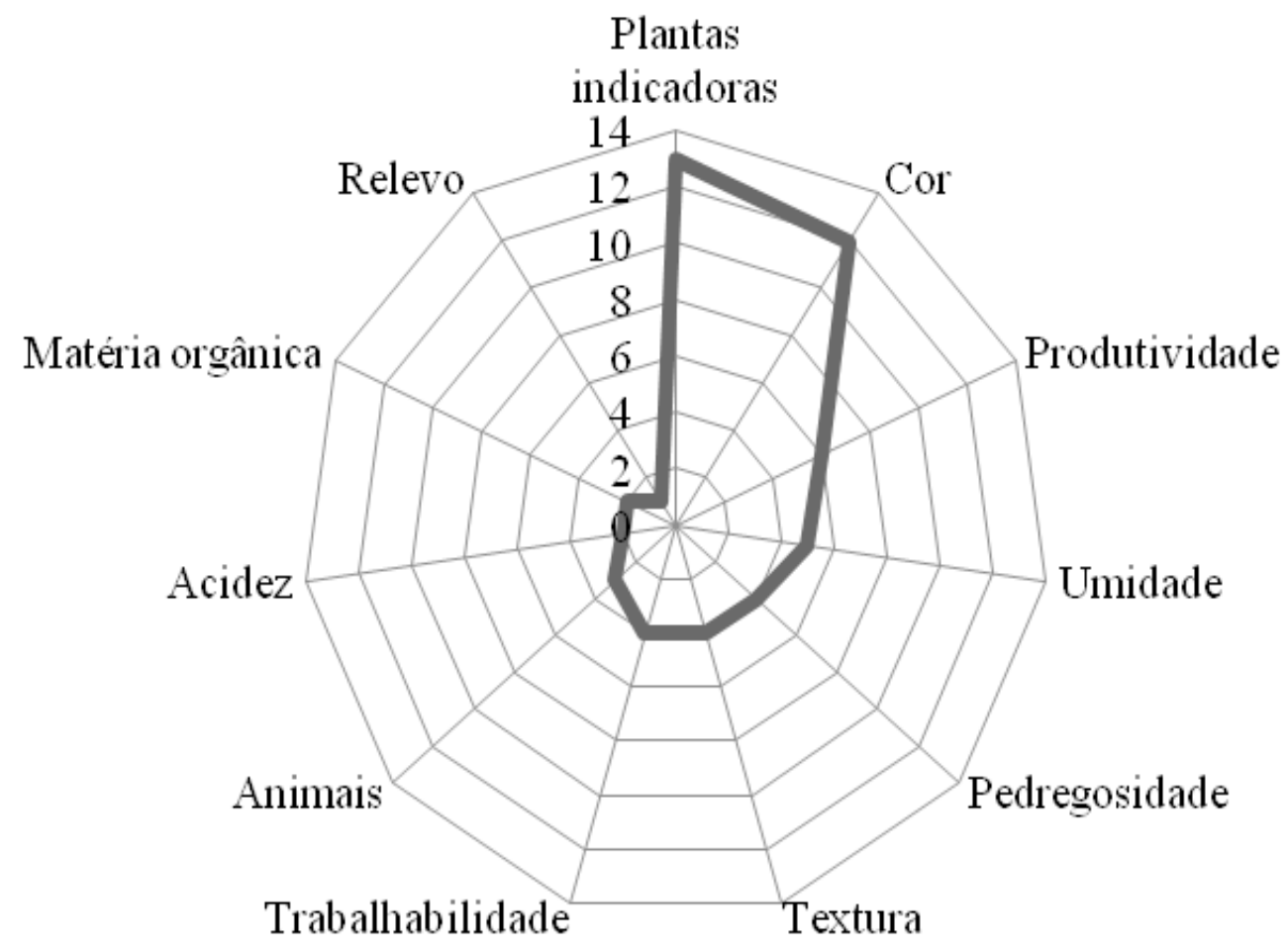

Fonte: STRACHULSKI, 2014.

Legenda: Gráfico em forma de radar, retratando os indicadores locais de qualidade das terras, cujo traço cinza mais espesso representa o número de citações para cada indicador, sendo que cada círculo do radar representa dois números, que vão de 0 a 14.

Na figura 6, tem-se o fator plantas indicadoras como o mais citado $\left(1^{\circ}\right)$ na fala dos agricultores, com 13 citações, demonstrando a importância dada aos conhecimentos herdados por estes e a necessidade da preservação e manutenção destes saberes e de sua tradição na comunidade.

Já a cor aparece como o segundo $\left(2^{\circ}\right)$ parâmetro indicador das qualidades das terras, salientando-se que a classificação através das cores simboliza terras melhores, terras piores, ou que precisam ser corrigidas, tanto pela adubação química como pela adubação verde.

O fator produtividade $\left(3^{\circ}\right)$ se refere tanto ao emprego de técnicas que protegem a terra, assim como a presença da palhada dos cultivos anteriores e do plantio direto, como das características da própria terra, fatores que acabam ou não ocasionando em uma boa produção. 
A matéria orgânica e umidade estão implícitas no discurso dos agricultores nas expressões que por muitas vezes foram citadas como "terras com gordura", "sem liga" e "seca”. A textura refere-se à capacidade de o agricultor perceber se uma terra é arenosa ou argilosa, influenciando na umidade da mesma.

A pedregosidade associa-se à trabalhabilidade, pois falam das dificuldades de cultivo nessas áreas devido a presença abundante de fragmentos de rocha (saibro) e pequena espessura, denotando um solo erodido. Outro fator ligado a pedregosidade é a conotação de boa fertilidade, sendo que também se remete ao dique de diabásio que dá origem a Terra Roxa, sendo esta uma terra boa, pois segundo o senhor Carlito Ponciano: "meu pai dizia que pra uma terra ser boa tinha que ter pedra".

Por meio das entrevistas pode-se perceber que foi dado destaque ao item espessura do solo como um fator limitante da qualidade das terras, sendo por eles referenciado principalmente ao desenvolvimento da cultura do feijão e milho, mas também aos demais cultivos (arroz, mandioca e outros). A espessura do solo é um aspecto marcante, que caracteriza a Terra Branca como terra ruim ou intermediária, pois segundo o agricultor Carlos Adonis: "o pior (da Terra Branca) é ser rasa, se fosse funda poderia segurar a umidade e a planta enraizar".

De acordo com a classificação local, as 'Terras Brancas' aparecem como ruins a intermediárias, citadas nas quatorze entrevistas, sendo que cinco citações a colocam como intermediária e nove como terra ruim.

Um fato importante acerca das Terras Brancas é percebido quando os agricultores falam de suas características, entendendo que já foram melhores no passado, pois a maioria compreende que atualmente são ruins. Referindo-se à análise do perfil de cultivo, a partir do conhecimento local, trata-se de "não considerar somente o estado físico atual do meio, mas ainda de buscar prever ou de compreender sua história” (HÉNIN et al., 1960, p. 04).

As Terras Amarelas, por exemplo, são compreendidas como as piores terras, citadas por três dos quatorze entrevistados. Já as Terras Roxas são consideradas as melhores terras, citadas em dez das quatorze entrevistas, classificando-as como boas, usando como parâmetros principalmente o cultivo de feijão e milho. Segundo o discurso local esta é uma terra em que a maioria dos cultivos tem um bom desenvolvimento.

Por outro lado, a principal característica das Terras Roxas ressaltada pelos agricultores: a "gordura", compreendida como o parâmetro matéria orgânica, é um elemento comum às concepções de fertilidade moderna e tradicional, corroborando com a congruência 
de saberes no que tange a esse parâmetro (PROMIPAC, 2001; FLORIANI, 2007; STRACHULSKI, 2011).

Os outros fatores mencionados como acidez, fauna edáfica e relevo demonstraram possuir menor importância na distinção da qualidade das terras pelos agricultores, sendo menos incorporados ao seu corpus. O conhecimento e uso local dos solos serve como um critério nodal na tomada de decisões sobre as formas de manejar as paisagens que formam o entorno local (TOLEDO; BARRERA-BASSOLS, 2008), tendo em vista que as diferentes paisagens (área agrícola, pastagens, reflorestamentos, etc.) são o resultado do entendimento local acerca da qualidade e potencialidade de suas terras.

Neste sentido, Porto Gonçalves (2002, p. 37) destaca a importância dos povos e comunidades que conviveram e convivem numa íntima relação com a natureza e que dela dependem, ressaltando que devem receber um maior respeito por parte dos pesquisadores, sobretudo no que tange "às suas matrizes de racionalidade que foram capazes de se desenvolver com e não contra essa natureza”.

Neste sentido, é importante salientar que as comunidades rurais, através da percepção da paisagem e da implantação de suas práticas agrícolas, vêm adaptando seus cultivos às condições ecológicas locais e desenvolvendo conhecimentos particulares acerca dos elementos paisagísticos. Não obstante a transformação da área modificada pela humanidade e sua apropriação para usufruto são de importância fundamental para planejar a forma de uso dos recursos naturais contidos na paisagem. Portanto,

\footnotetext{
El paisaje rural es el resultado de la interacción entre la sociedad y el medio en que ésta se asienta. Esta ocupación se plasmará en una específica ordenación de los espacios para ponerlos en valor teniendo en cuenta las relaciones que se establecen entre las estructuras físico-ecológica y la socio-económica. Entendida esta correlación en una doble vertiente, por un lado, las interacciones complejas, dinámicas y cambiantes fruto de los procesos sociales y económicos que conforman el territorio y, por otra, las valoraciones sociales y culturales que esa sociedad tiene de su territorio (HERNÁNDEZ HERNÁNDEZ, 2009, p. 170).
}

Assim, na mente dos agricultores de Linha Criciumal não existe um conhecimento acerca dos solos que esteja separado ou sem conexão com outros elementos de sua paisagem produtiva, quase sempre o relacionando com, vegetação, água, cor, dentre outros. Nestes termos, Porto Gonçalves (2002) destaca os saberes tradicionais por sua capacidade holística de interpretação da realidade, e sua não-linearidade, ou seja, seria dizer que são conhecimentos que se (re)produzem de forma circular, sem que hajam desconexões e/ou esquecimentos. 


\section{AS PLANTAS INDICADORAS DA QUALIDADE DAS TERRAS: CONECTANDO OS ELEMENTOS DA PAISAGEM}

A partir dos dados acima expostos, percebe-se que para dizer se as terras são boas ou ruins, "fortes" ou "fracas", vários são os atributos incorporados na representação local da fertilidade das terras, contudo, aquele que permite de forma mais explicita perceber a qualidade das terras é o fator plantas indicadoras.

Desta forma, as plantas indicadoras podem ser compreendidas como o modo de inferir quanto à fertilidade das terras mais perceptível na paisagem rural. São os elementos diagnóstico-vernaculares que mais demonstram a estreita ligação das práticas produtivas, sintetizadas nos saberes locais, com o agroecossistema e sua materialização na paisagem como um todo (STRACHULSKI, 2011).

Muitas espécies vegetais espontâneas podem indicar indiretamente a qualidade do solo, compreendendo-se que espécies indicadoras são aquelas que respondem às transformações do meio que vivem mediante seu desaparecimento, decadência ou vigor e abundância no crescimento e na ampliação de sua capacidade de reprodução (LARCHER, 2000).

O uso de plantas indicadoras da qualidade das terras, apesar de ser pouco explorado por pesquisadores, é intrínseco ao complexo $k-c-p^{3}$ inerente ao agricultor, tendo em vista que tradicionalmente se utilizam grupos de plantas nativas como indicadoras, pois a convivência diária com o agroecossistema lhes possibilita percepções aguçadas acerca da qualidade das terras. Tal conhecimento é o resultado de uma interação entre o agricultor e o agroecossistema em relação às terras e plantas presentes naquela paisagem (TOLEDO; BARRERA-BASSOLS, 2009). A paisagem rural, nestes termos,

[...] es, portanto, donde más se evidencian las influencias de los tres grupos de elementos (abióticos, bióticos y antrópicos), y en el que pueden presentar un grado de jerarquía similar. Caso distinto del paisaje natural, donde dominan elementos abióticos y bióticos, y del urbano, donde domina los elementos antrópicos (RIBAS VILAS, 1992, p. 250).

Neste sentido, a paisagem rural pode ser compreendida como um caleidoscópio, em que a cada momento os elementos se combinam de uma forma diferenciada a medida que as interações vão ocorrendo. Assim, ela não é estática nem imutável, é "um processo criativo permanente" (TABET, 1989, p. 442). Da mesma forma, não são estáticos os conhecimentos resultantes do manejo desta paisagem.

\footnotetext{
Para Toledo e Barrera-Bassols (2009), a compreensão dos saberes tradicionais centra-se no estudo do complexo kosmos-corpus-praxis (k-c-p). Assim, explora as maneiras como a natureza é visualizada pelos diferentes grupos humanos (culturas), através de um conjunto de crenças (kosmos) e conhecimentos (corpus), e como em termos destas imagens, tais grupos utilizam e/ou manejam (praxis) os recursos naturais (TOLEDO; BARRERA-BASSOLS, 2009).
} 
Para os agricultores de Linha Criciumal o conhecimento e classificação das plantas e sua correlação aos tipos de terras só faz sentido se for construído com base em um conhecimento prático, como o cultivo e preparo da terra e/ou práticas sociais ligadas a organização do trabalho. Os agricultores aproveitam estes momentos para compartilhar experiências cotidianas e reproduzir as antigas experiências trazidas das gerações passadas.

O saber relativo às plantas indicadoras é sintético, porque reúne dados da paisagem tais como relevo, solos, micro-clima e vegetação. Assim, os agricultores conseguem identificar o tipo de terra por meio das espontâneas, preponderantemente com base em três aspectos principais: a cor da folha, o seu porte e o vigor no crescimento, além da textura (folha mole). Desta maneira, podem fazer inferências quanto às qualidades de suas terras (boas ou fortes, e ruins ou fracas) e os limites e potencialidades de suas paisagens.

Já a identificação e distinção entre as espécies vegetais se dá observando elementos como: seu porte, as flores (forma e cor), a casca (cor e forma) e as folhas (tamanho, forma, textura) quando se trata de árvores, e diferenças de cor, forma da planta, porte, cheiro e presença ou ausência de espinhos quando se trata de herbáceas e lianas.

Os agricultores locais possuem em comum várias técnicas de manejo dos recursos naturais, além das práticas de sociabilidade, entretanto, "certas pessoas são mais observadoras e provam ter um espírito mais curioso: seu olhar percebe mais detalhes e revela configurações que escapam aos outros" (CLAVAL, 2007, p. 81).

Assim, para alguns agricultores as plantas espontâneas são entendidas como verdadeiras "pragas", por dificultarem o seu trabalho e atrapalharem o desenvolvimento dos cultivos, já outros entendem sua importância e a relacionam a cobertura do solo e a produção de adubo, como aponta o agricultor Mariano Krul: "Se não tivesse esses mato a terra se acabava".

A percepção ecológica destes agricultores tanto é fruto do conhecimento coletivo compartilhado por toda comunidade, como do individual, pois há alguns termos e conhecimentos que são exclusivos de um e outro indivíduo, devido as suas características culturais, pelo corpus que lhe é transmitido, pelas práticas resultantes deste corpus, e seu imaginário que traz vida e sentido ao conjunto de conhecimentos e de práticas.

Em termos comparativos (quadro 1), verificou-se que um tipo de terra pode ser correlacionada com dois tipos de solos. Isto é corroborado pela fala dos agricultores que apesar de identificarem um tipo só de terra (Branca, Amarela ou Roxa) ressaltam também que há manchas de terras boas nas terras ruins e vice-versa.

Tabela 1 - Correspondências entre a classificação vernacular e científica acerca das terras, parâmetros 
pedológicos e plantas indicadoras na comunidade Linha Criciumal

\section{QUALIDADE DOS SOLOS E PLANTAS INDICADORAS}

\begin{tabular}{|c|c|c|c|c|c|c|c|c|c|c|c|c|c|c|c|}
\hline \multirow[b]{2}{*}{ Perfis } & \multirow[b]{2}{*}{ Família } & \multirow[b]{2}{*}{ Gênero/Espécie } & \multirow[b]{2}{*}{$\begin{array}{l}\text { Nome } \\
\text { popular }\end{array}$} & \multirow{2}{*}{$\begin{array}{c}\text { Classificação } \\
\text { vernacular } \\
\text { das terras }\end{array}$} & \multirow{2}{*}{$\begin{array}{l}\text { Qualidade } \\
\text { das terras }\end{array}$} & \multirow{2}{*}{$\begin{array}{l}\text { Características } \\
\text { das terras }\end{array}$} & \multirow{2}{*}{$\begin{array}{l}\text { Taxonomia } \\
\text { pedológica }\end{array}$} & \multirow{2}{*}{$\begin{array}{l}\text { Horizonte } \\
\text { superficial }\end{array}$} & \multicolumn{2}{|c|}{$\begin{array}{c}\text { Parâmetros físicos } \\
\text { dos solos }\end{array}$} & \multicolumn{5}{|c|}{ Parâmetros químicos do Hor. A } \\
\hline & & & & & & & & & $\begin{array}{l}\text { Espessura } \\
\text { dosolum }\end{array}$ & $\begin{array}{c}\text { Relação } \\
\text { textural } \\
\text { A/B }\end{array}$ & $\begin{array}{c}\mathrm{pH} \\
(\mathrm{CaCl} 2)\end{array}$ & $\begin{array}{c}\text { C.T.C. } \\
\text { (cmold } \\
\left.\mathrm{dm}^{3}\right)\end{array}$ & V (\%) & $m(\%)$ & $\begin{array}{l}C(g / \\
\left.d m^{3}\right)\end{array}$ \\
\hline \multirow{5}{*}{1} & Asteraceae & $\begin{array}{c}\text { Parthenium } \\
\text { hysterophorus L. }\end{array}$ & $\begin{array}{l}\text { Tomatiro/ } \\
\text { Catarinete }\end{array}$ & \multirow{5}{*}{ Roxa } & \multirow{5}{*}{ Boa/Forte } & \multirow{5}{*}{$\begin{array}{c}\text { Gordurosa/ } \\
\text { De massa; } \\
\text { Pedregosa/ } \\
\text { Pedrenta; } \\
\text { Funda; Úmida; } \\
\text { Solta; }\end{array}$} & \multirow{5}{*}{$\begin{array}{c}\text { Neossolo } \\
\text { Litólico } \\
\text { eutrófico } \\
\text { fragmentário }\end{array}$} & & \multirow{5}{*}{$\begin{array}{c}0-20 \\
\mathrm{~cm}\end{array}$} & \multirow{5}{*}{ Franca } & \multirow{5}{*}{6,3} & \multirow{5}{*}{32,28} & \multirow{5}{*}{90} & \multirow{5}{*}{0} & \multirow{5}{*}{57} \\
\hline & Euphorbiaceae & $\begin{array}{l}\text { Ricinus communis } \\
\qquad .\end{array}$ & Mamona & & & & & & & & & & & & \\
\hline & Fabaceae & $\begin{array}{l}\text { Inga marginata } \\
\text { Willd. }\end{array}$ & Ingazeiro & & & & & Moderado & & & & & & & \\
\hline & Phytolaccaceae & $\begin{array}{l}\text { Phytolacca } \\
\text { americana L. }\end{array}$ & Caruru-roxo & & & & & & & & & & & & \\
\hline & Verbenaceae & $\begin{array}{l}\text { Aloysia virgata (Ruiz } \\
\text { \& Pav.) Juss. }\end{array}$ & Lixeira & & & & & & & & & & & & \\
\hline 2 & Idem ao 1 & Idem ao 1 & Idem ao 1 & Roxa & Boa/Forte & Idem ao 1 & $\begin{array}{l}\text { Argissolo } \\
\text { Vermelho } \\
\text { eutrófico } \\
\text { nitossólico }\end{array}$ & $\begin{array}{c}\text { A } \\
\text { Proeminente } \\
(32 \mathrm{~cm})\end{array}$ & $\begin{array}{c}>150 \\
\mathrm{~cm}\end{array}$ & $\begin{array}{l}\text { Franca/ } \\
\text { Argilosa }\end{array}$ & 6,0 &, 55 & 74,5 & 0 & 14 \\
\hline \multirow{4}{*}{3} & Dennstaedtiaceae & $\begin{array}{l}\text { Pteridiumaquilinum } \\
(\text { L.) Kuhn var. }\end{array}$ & Samambaia & \multirow{4}{*}{ Branca } & \multirow{4}{*}{$\begin{array}{l}\text { Intermediária/ } \\
\text { Ruim Fraca }\end{array}$} & \multirow{4}{*}{$\begin{array}{c}\text { Seca; Dura/ } \\
\text { Firme/Pisoada; } \\
\text { Rasa; Arenosa/ } \\
\text { Areienta; } \\
\text { Pedregosa/ } \\
\text { Pedrenta; } \\
\text { Ácida; Batuma }\end{array}$} & \multirow{4}{*}{$\begin{array}{c}\text { Cambissolo } \\
\text { Háplico Ta } \\
\text { eutrófico } \\
\text { léptico }\end{array}$} & & & \multirow{4}{*}{$\begin{array}{c}\text { Franco- } \\
\text { siltosa/ } \\
\text { Franco- } \\
\text { siltosa }\end{array}$} & \multirow{4}{*}{6,1} & \multirow{4}{*}{13,35} & \multirow{4}{*}{77,9} & \multirow{4}{*}{0} & \multirow{4}{*}{27} \\
\hline & Malvaceae & Sida rhombifolia L. & Guanxuma & & & & & Moder: & $0-9$ & & & & & & \\
\hline & Poaceae & $\begin{array}{c}\text { Imperata brasiliensis } \\
\text { Trin. }\end{array}$ & Sapé & & & & & $(15 \mathrm{~cm})$ & $\mathrm{cm}$ & & & & & & \\
\hline & Rubiaceae & Richardiascabra L. & Erva-quente & & & & & & & & & & & & \\
\hline
\end{tabular}


Saber ecológico tradicional da comunidade rural linha criciumal, Cândido de Abreu - PR:

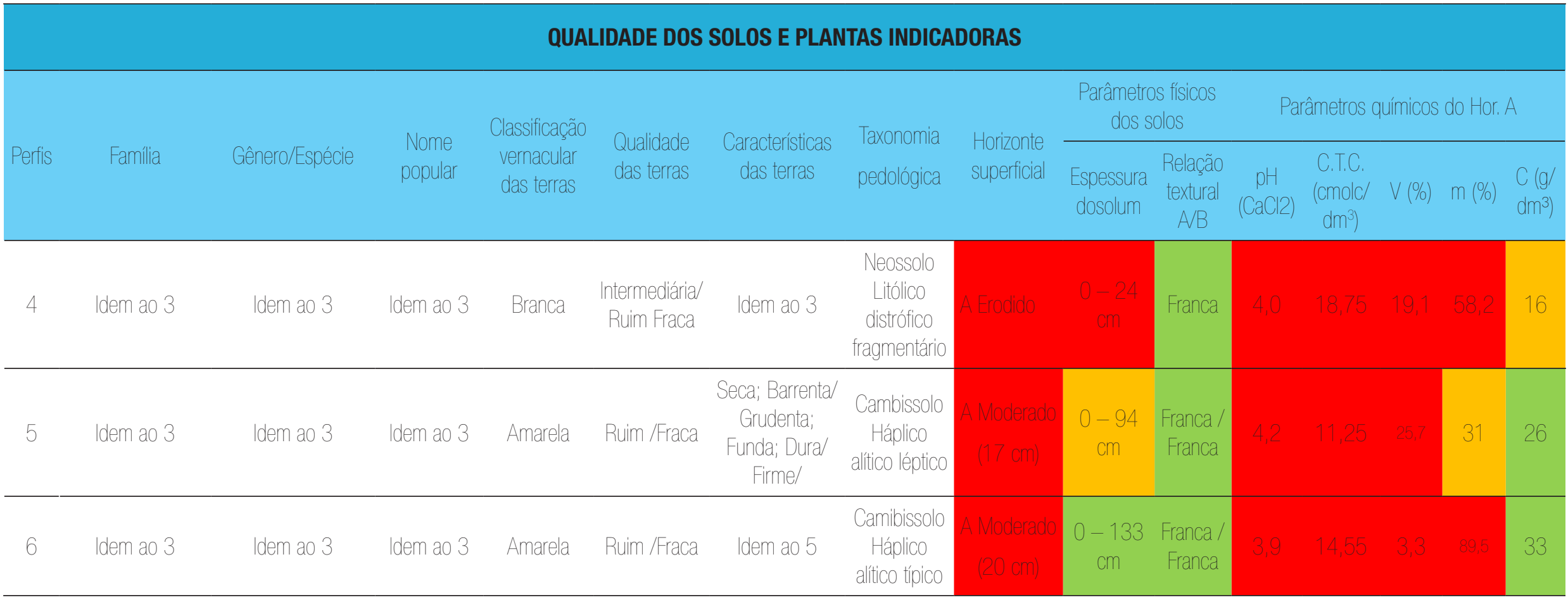

\section{Legenda:}

Boa qualidade do solo

Média qualidade do solo

Máa qualidade do solo

Fonte: STRACHULSKI, 2014. 
Verificou-se que as Terras Brancas correspondem cientificamente ao CAMBISSOLO Háplico Ta eutrófico léptico e NEOSSOLO Litólico distrófico fragmentário. Este tipo de terra é percebido por alguns agricultores como intermediaria e pela maioria como fraca/ruim, e, na condição de terra ruim possui algumas plantas a ela relacionadas como a samambaia, guanxuma (figura 7), sapé e, em especial, a erva-quente, que segundo os agricultores quando esta aparece "é o último da terra". O nome erva-quente se deve aos agricultores perceberem que esta planta ao se alastrar pelo chão acaba cobrindo a superfície, retendo o calor emitido pelo sol, secando as plantas de feijão, provocando a sua morte.

\section{Figura 7 - 0 diálogo de saberes em relação a terras e plantas indicadoras}

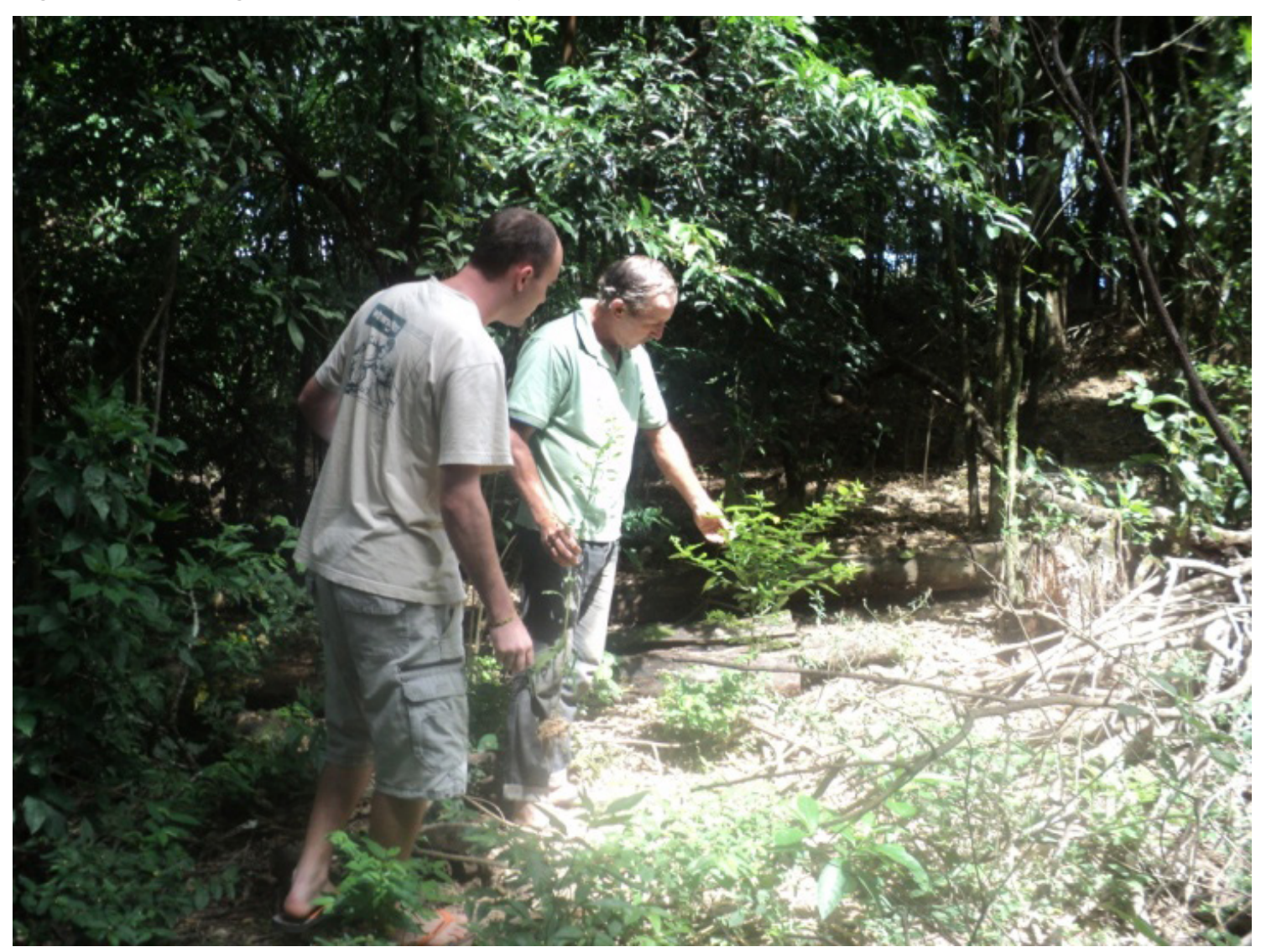

Fonte: STRACHULSKI, 2014 (foto tirada por morador local).

Legenda: $O$ agricultor apresenta a guanxuma, planta indicadora de terra Branca (Ruim), em conversa com o pesquisador em área de lavoura próxima a um fragmento de vegetação.

Destarte, corrobora-se com outros estudos (ARAÚJO 2007; SILVA, 2010; STRACHULSKI, 2011) que também retratam as espécies vegetais espontâneas, na compreensão da relação entre plantas e terras, como a forma mais prática e perceptível dos agricultores classificarem os solos em termos de sua qualidade. 
Uma característica marcante em algumas manchas nas Terras Brancas que se percebe após a chuva é a formação de uma espécie de crosta compacta na superfície que age impedindo o desenvolvimento das raízes das plantas, diminuindo a infiltração da água no solo e aumentando o escoamento superficial das águas das chuvas. Quando isto ocorre os agricultores dizem que, "a terra batuma”, fenômeno também percebido por Gomes (2011) em relação aos agricultores da região sudeste do Paraná.

Em Linha Criciumal o encrostamento ocorre devido a utilização pretérita de instrumentos para revolver o solo, o que acabou destruindo seus macroporos, mediante o rebaixamento da superfície, e que atualmente tem provocado erosão laminar e pequenos sulcos na maioria das propriedades em que se encontra a Terra Branca.

Desta forma, a Terra Branca apresenta características pouco ideais ao desenvolvimento das plantas de feijão como pequena espessura, acidez, baixa saturação por bases (macronutrientes), saturação por alumínio elevada (58,2\%) em um dos solos e muito susceptíveis à erosão, devido às altas declividades. Portanto, os resultados da análise científica corroboram a percepção local acerca da qualidade das Terras Brancas, em relação aos principais parâmetros físico-químicos e morfológicos, pois os solos identificados nestas terras apresentam características pouco ideais ao desenvolvimento das plantas de feijão.

O elemento cor aparece também como um fator de correspondência entre o nome local do solo designado por Terra Branca com a cor atribuída por métodos científicos, que apresenta variações de Cinzento a Cinzento-brunado-claro.

Para as Terras Brancas (Cambissolo Háplico Ta Eutrófico léptico e Neossolo Litólico Distrófico fragmentário) a baixa espessura do horizonte A no primeiro solo e ausência deste no segundo, em conjunto com a textura do horizonte superficial franco-siltosa e franca respectivamente, denotam solos com baixa plasticidade e pegajosidade, além de uma baixa resistência ao ar quando seco. Tais informações são corroboradas pelo conhecimento local, pois segundo o agricultor Carlito Ponciano: "(Terra) Branca, se dá um vento leva a terra", e Bruno Czerski, para quem: "(Terra) Branca não é liguenta (e) se fazer um pelote com essa terra ele quebra", o que evidencia condições físicas pouco favoráveis ao desenvolvimento das plantas de feijão.

Por outro lado, às características do relevo, embora apresentem pré-disposição à remoção de substâncias (sedimentos, água e nutrientes) do perfil do solo por erosão hídrica, possibilitam relativa condição sanitária as plantas, diminuindo a incidência de doenças bacterianas e fúngicas. 
As Terras Amarelas, por sua vez, citadas por três pessoas, aparecem como as piores terras e estão relacionadas ao Cambissolo Háplico Alítico léptico e Cambissolo Háplico Alítico típico e pode-se dizer que as mesmas plantas indicadoras de terra ruim encontradas nas Terras Brancas também estão presentes nas Terras Amarelas.

Em comparação as Terras Brancas, as Terras Amarelas, consideradas as piores pelos agricultores, possuem solos mais espessos, contudo, suas características químicas são mais severamente negativas no tocante à cultura do feijão e outros cultivos alimentares. Sua pior característica elegida pelos agricultores, porém é ser "grudenta", pois segundo estes a "Terra Amarela é grudenta, a planta não gosta, raiz não cresce, precisa de espaço”. Nestes tipos de terras se encontra a textura franca que apresenta um equilíbrio nas proporções entre as frações areia, silte e argila, indicando uma textura ideal para os cultivos, contudo, na visão dos agricultores se torna um impeditivo ao seu desenvolvimento.

Percebe-se que para o diagnóstico da aptidão agrícola dessas terras, deve-se levar em conta um conjunto de atributos que não somente privilegiem as características químicas dos solos como destacado em esquemas convencionais de avaliação da aptidão agrícola das terras (FLORIANI, 2007). Portanto, se tratando de um trabalho etnocientífico, os pressupostos de valor ou as normas de fertilidade que o pesquisador pode ser tentado a estabelecer devem estar atrelados aos critérios de avaliação inerentes ao grupo social referido (CHEVERRY et al., 1995).

Assim, ocorre uma incongruência entre o saber local e o conhecimento científico, tendo em vista que certas especificidades locais só são percebidas graças ao convívio quase que diário das populações locais com determinados ambientes. Tal fato proporciona um conhecimento extremamente vinculado às condições do ambiente físico local ao ponto de ser mais eficiente que o conhecimento científico em várias situações.

Corroborando ao acima exposto, Porto Gonçalves (2002) destaca a necessidade de se pensar a relação sociedade-natureza de uma forma menos banal e economicista, para uma que destaque a relação de equilíbrio, ou seja, das sociedades com e não contra a natureza. Portanto, dever-se-ia dar mais importância as populações indígenas e camponesas que possuem um acervo cultural riquíssimo, bem como um conhecimento do meio biofísico (solos e plantas) capaz de possibilitar manejos condizentes com as capacidades produtivas dos ecossistemas em que vivem.

Deste modo, foi verificado que houve consonância, em termos gerais, entre conhecimento científico e saber popular no tocante à qualidade destas terras. Situações que afirmam tal hipótese são: má qualidade química, sendo solos ácidos para o cultivo de 
feijão, segundo os padrões agronômicos modernos (o ideal é um pH de 6,0 a 6,5, segundo técnicos da EMATER de Cândido de Abreu), apesar de possuírem uma textura (franca) favorável ao desenvolvimento de cultivos, carbono elevado e relativa espessura do solum.

Contudo, possuem uma baixa saturação por bases (macronutrientes), alta saturação do complexo sortivo por alumínio tóxico e um valor baixo de C.T.C, indicando que o solo possui baixa capacidade para reter cátions em forma trocável, ou seja, a solução do solo disponibiliza as raízes das plantas poucos nutrientes.

A cor do solo, por sua vez, também evidencia a correlação de saberes em torno da Terra Amarela, pois a cor atribuída por métodos científicos apresenta correlação com o nome local, variando de Bruno a Bruno-amarelado ao longo do perfil.

Com o entendimento de que as características destes tipos de terras são negativas, alguns agricultores falaram em plantar pasto e eucalyptus nas terras Branca e Amarela, pois percebem que estas estão cada vez mais “fracas", entendendo que já foram melhores do que hoje em dia. Esta situação,

Reflete, portanto, o patrimônio material e imaterial dos agroecossistemas derivado da história coevolutiva entre a espécie humana, as espécies vegetais e animais domesticadas e os ecossistemas (o potencial de adaptação das plantas frente às restrições ambientais), refletindo a herança biocultural de um grupo social em uma dada região (FLORIANI et al., 2014, p. 32).

Em relação às Terras Roxas, entendidas como as melhores terras, foram associados o Neossolo Litólico Eutrófico fragmentário e Argissolo Vermelho Eutrófico nitossólico, relacionando-se a elas plantas indicadoras como o Tomateiro/Catarinete, Mamona, Ingazeiro, Caruru-roxo, Lixeira, dentre outros.

Evidenciou-se congruência entre o saber local e o conhecimento científico no que tange a qualidade dos solos sob Terras Roxas, pois, do ponto de vista dos parâmetros agronômicos modernos tais solos apresentam boa qualidade físico-química e morfológica, corroborando a alcunha de terra boa.

Apesar de um dos solos ter sido classificado como Neossolo, com um horizonte A Moderado de $20 \mathrm{~cm}$ e em sequência a rocha matriz (características negativas para um solo) e ambos serem muito susceptíveis à erosão, devido às altas declividades, possuem uma textura franca no horizonte superficial, o que favorece o desenvolvimento das raízes dos cultivos. A principal característica das Terras Roxas ressaltada pelos agricultores: a "gordura", compreendida como o parâmetro matéria orgânica, é um elemento comum às concepções de fertilidade moderna e tradicional, corroborando a congruência de saberes no que tange a esse parâmetro (PROMIPAC, 2001; FLORIANI, 2007; STRACHULSKI, 2011). 
O conhecimento científico em termos químicos coaduna com o conhecimento local quando diz estas serem terras boas, pois o Argissolo encontrado nestas possui um solum espesso de mais de $150 \mathrm{~cm}$. Já o $\mathrm{pH}$ dos dois solos é considerado ideal para o cultivo do feijão (mas não para o milho, segundo os agricultores), segundo as condições locais. A C.T.C (Capacidade de Troca de Cátions) é relativamente alta com base no Argissolo, saturação por bases elevada e saturação por alumínio inexistente, indicando baixa concentração de elementos tóxicos as raízes dos cultivos, além de matéria orgânica em nível alto de concentração (Neossolo: 98,4 g/ $\mathrm{dm}^{3}$ e Argissolo: 24,04 g/ $\mathrm{dm}^{3}$ ), corroborando a "gordura" encontrada nestas terras.

Por sua vez, a cor do solo também indica congruência entre as formas de saberes, pois o nome local Terra Roxa, por vezes dita "meio avermelhada", possui forte relação com o nome da cor atribuído de forma científica, que vai de Bruno-avermelhado-escuro a Bruno-escuro.

De certa forma, os agricultores reconhecem que na maior parte do território da comunidade as terras não são boas naturalmente, e segundo o agricultor Carlos Adonis as pessoas "acham que as terras são boas por ter se acostumado a elas, mas em outro lugar tem melhor", ou seja, identificam as melhores terras em suas propriedades, mas entendem que em outros lugares há terras melhores.

Já a identificação das plantas indicadoras e a distinção entre espécies se deram segundo vários aspectos locais, que possuem forte correlação com os quesitos científicos levados em consideração para sua identificação. Desta maneira, para identificar as espécies indicadoras da qualidade das terras, foram levados em consideração elementos como: o porte (tamanho), as flores (forma e cor), a casca (cor e forma) e as folhas (tamanho, forma, textura) quando se tratou de árvores, e diferenças de cor, forma da planta, porte, cheiro e presença ou ausência de espinhos quando se tratou de herbáceas.

A utilização de plantas para se identificar a qualidade das terras se assenta no fato de que "não há meios oligotróficos, há solos mais ricos e mais pobres em nutrientes, suportando plantas adaptadas a cada caso" (RIZZINI, 1997, p. 60). Neste sentido, a utilização de espécies nativas como as apontadas pelos agricultores são os elementos que melhor assinalam a situação nutricional dos solos, pois as plantas cultivadas por não estarem adaptadas a pequenos teores de nutrientes, muitas vezes bem abaixo do que estão acostumadas, não suportam e definham ou morrem.

Desta forma, vale destacar que o conhecimento ecológico do agricultor vernacular não é a soma de conhecimentos disparatados, mas sim o resultado de percepções diárias que 
permitem interconectar os elementos naturais aos socioculturais, moldando a paisagem local, de modo que,

(...) na mente do produtor tradicional existe um detalhado catálogo de conhecimento acerca da estrutura ou dos elementos da natureza, as relações que se estabelecem entre estes, seus processos e dinâmicas e seu potencial utilitário". Dessa forma, no saber local existem conhecimentos detalhados de caráter taxonômico sobre constelações, plantas, animais, fungos, rochas, (...) solos, paisagens e vegetação, ou sobre processos geofísicos, biológicos e ecológicos, tais como movimentos de terras, ciclos climáticos ou hidrológicos, ciclos de vida, períodos de floração, frutificação, germinação (...) e fenômenos de recuperação de ecossistemas (sucessão ecológica) ou de manejo da paisagem (TOLEDO; BARRERABASSOLS, 2009, p. 36).

Portanto, em Linha Criciumal os agricultores possuem um acervo de conhecimentos que herdaram ao longo do tempo e ao largo da Geografia, porque são específicos das paisagens em que as pessoas estão inseridas. Também são processos inacabados de produção do conhecimento cuja capacidade inventiva do ser humano a partir do contato com uma situação adversa (novo quadro temporal) acaba proporcionando a metamorfose de tais conhecimentos, que além de acúmulos são a intersecção de visões distintas sobre processos variados.

\section{CONSIDERAÇÕES FINAIS}

O presente estudo buscou a revalorização do conhecimento vernacular de agricultores da comunidade rural Linha Criciumal, bem como compreender sua relação com a paisagem rural de seu território. Tal valorização se dá em um contexto atual de crise da modernidade onde as práticas científicas hegemônicas são contestadas por não dar conta e, sobretudo, por desconsiderar as complexidades socioterritoriais.

Sendo um dos enfoques que mais têm contribuído para estudar o conhecimento das populações tradicionais, as etnociências, em específico a etnoecologia, com seu enfoque interdisciplinar e abrangente, ajudou a compreender a lógica por trás do conhecimento das comunidades rurais acerca do mundo natural. Nesse sentido, o estudo destaca a estrutura cognitiva êmica da comunidade rural em questão, as taxonomias e classificações dos elementos do meio físico (vegetação e solos).

A matriz cognitiva coletiva acerca dos aspectos agrícolas das terras da paisagem local ganha importância com as representações espaciais que nascem da vivência nesta paisagem, das experiências cotidianas incorporadas ao longo da vida, que criam representações coletivas sobre as qualidades de suas terras e os elementos que indicam estas qualidades (plantas 
indicadoras). Estas representações estão intrinsecamente ligadas ao conhecimento prático como o cultivo e preparo da terra e/ou práticas sociais ligadas à organização do trabalho.

A identificação e mapeamento dos três tipos de terras e plantas indicadoras a elas referenciadas pelo saber vernacular, bem como os solos identificados por meio da descrição dos perfis, classificados de acordo ao Sistema Brasileiro de Classificação de Solos, possibilitaram uma melhor compreensão da relação da comunidade com a paisagem, destacando-se a valorização de certos elementos biofísicos por parte dos agricultores (solos e plantas). Desta forma, obteve-se a correlação entre os atributos científicos e vernaculares referentes à qualidade das terras, bem como da correlação das plantas indicadoras aos tipos de terras e destas com os tipos de solos.

As Terras Brancas, consideradas intermediárias por alguns e ruim pela maioria, foram associados o Cambissolo Háplico Ta Eutrófico léptico e Neossolo Litólico Distrófico fragmentário e sua qualidade a plantas indicadoras como samambaia, guanxuma, sapé, erva-quente, etc. Tal correlação apresentou-se congruente, pois estas terras, em termos gerais, foram consideradas ruins e os solos a elas associados também foram considerados ruins de acordo aos parâmetros científicos.

Consideradas terras ruins assim como as Brancas, as Terras Amarelas aparecem com as piores, relaciondo-se ao Cambissolo Háplico Alítico léptico e Cambissolo Háplico Alítico típico, sendo que as mesmas plantas indicadoras de terra ruim encontradas nas Terras Brancas também estão presentes nas Terras Amarelas. A análise química destes solos indica características químicas mais negativas do que das Terras Brancas, coadunando com o discurso dos agricultores que dizem ser terra ruim.

Em relação às Terras Roxas, entendidas como as melhores terras (terras boas), foram associados o Neossolo Litólico Eutrófico fragmentário e Argissolo Vermelho Eutrófico nitossólico, e, sendo terras boas a elas foram relacionadas plantas indicadoras de sua qualidade, como o tomateiro/catarinete, mamona, ingazeiro, caruru-roxo e lixeira. Evidenciou-se congruência entre o saber local e o conhecimento científico, pois de acordo a análise físico-química e dados morfológicos tais solos apresentam boa qualidade.

A busca da correlação entre os saberes científico e vernacular, que possuem certas diferenças quanto a classificação e qualificação dos elementos naturais, torna-se difícil devido a capacidade de improviso do saber local e a rigidez dos métodos científicos. Entretanto, as correlações feitas apontam que é possível a realização de trabalhos com este enfoque, que visam aliar entre si áreas diferentes do conhecimento formal e essas com o saber local, buscando a revalorização desses. 
Assim, o conceito de paisagem aliado as etnociências possibilitou compreender a relação estabelecida entre o conhecimento ecológico local e o meio a sua volta, dando ênfase ao elemento natural solo e biótico flora.

A percepção da paisagem, por meio das plantas indicadoras, permite ao agricultor eleger as terras que ofereçam condições mais adequadas ao desenvolvimento de uma população ou comunidade (ecossistema agrícola). Isto demonstra que a noção de paisagem se apresentou um elemento de ligação entre o conhecimento ecológico local, as etnociências e o conhecimento científico, pois ele tanto possui características científicas, como não científicas.

Portanto, a importância do estudo dos saberes tradicionais para a geografia está no fato de compreender a relação entre sociedade e natureza sob uma ótica menos economicista e mais humanista. Como bem ressalta Claval (1999) tais saberes versam sobre as formas de viver no mundo, o savoir-faire (as práticas, habilidades), e tratam do mundo em que se vive (ambientes nos quais vivem os grupos). “Os geógrafos descobriram a importância das idéias que os povos primitivos tinham de seu meio ambiente, de suas estruturas sociais ou de suas relações com outros mundos" (CLAVAL, 1999, p. 69).

Assim, os saberes tradicionais também podem ser considerados saberes geográficos vernaculares, cujo valor para a Geografia reside no fato de proporcionarem um retorno ao passado que pode ajudar a criar condições para uma metamorfose da relação entre sociedade e natureza, possibilitando informações e pistas para uma relação mais equilibrada. Claval (2002) destaca que o interesse da Geografia pelas geografias vernaculares, pelos conhecimentos dos outros, está no interesse por tentar entender os conhecimentos de mundo do grupos humanos, inerentes aos saberes geográficos, buscando apreender as particularidades dos ambientes e das paisagens ligadas a determinadas sociedades (culturas).

O enfoque etnocientífico, por sua vez, permitiu a interpretação da estrutura cognitiva sobre as qualidades das terras, visto que as etnociências também tem por característica compreender o saber local e, na medida do possível, relacioná-lo ao conhecimento científico, possibilitando apreender um conjunto de informações que constituem o ambiente visível e invisível, real e imaginário, do mundo das comunidades detentoras desta forma de saber. 


\section{REFERÊNCIAS}

1. ALBUQUERQUE, U. P.; LUCENA, R. F. P.; CUNHA, L. V. F. C. Métodos e técnicas na pesquisa etnobiológica e etnoecológica. 1. ed. Recife: NUPEEA, 2010. (Coleção Estudos e Avanços).

2. ALVES, Â. G. C.; MARQUES, J. G. W. Etnopedologia: uma nova disciplina? Tópicos em Ciência do Solo, v. 4, p. 321-344, 2005.

3. ARAÚJO, J. C. L. Atributos do solo na interpretação do conhecimento de índios Guarani Mbya sobre terras para agricultura.2007.73 f. Dissertação (Mestrado em Agronomia) - Universidade Federal Rural do Rio de Janeiro. Seropédica. 2007. Disponível em: <http://www.ia.ufrrj.br/ cpacs/arquivos/teses_dissert/15_Julio_Cesar_Lucena.pdf >. Acesso em: 25de junho de2013.

4. BANDEIRA, F. P.S. F.Um estudo em perspectiva: etnopedologia e etno-ecogeografia do grupo indígena Pankararé. Cadernos de Geociências (UFBA), v. 5, p. 107-128, 1996.Disponível em: $<$ http://www.portalseer.ufba.br/index.php/cadgeoc/article/viewFile/4437/3546>. Acesso em: 25 de abril de2013.

5. BERQUE, A. Paisagem-marca, paisagem-matriz: elementos da problemática para uma geografia cultural. In: CORREA, R. L.; ROSENDAHL, Z. (Orgs.). Paisagem, tempo e cultura. 2. ed. Rio de Janeiro: Ed UERJ, 1998, p. 84-91.

6. BESSE, J-M. Habiter: un monde à mon image. Paris: Flammarion, 2013.

7. CHEVERRY, C; CURMI, P.; GRIMALDI, C.; GRIMALDI, M. La pédologie: débat autours de différents regards sur le sol. Revue Natures, Sciences, Sociétés, v. 3, n. 3, p.245- 251, 1995.

8. CLAVAL, P. Etnogeografias - Conclusão. Espaço e Cultura, Rio de Janeiro, n. 7, p. 69-74, jan./ jun. 1999.

9. CORCUFF, P. As Novas Sociologias: construções da realidade social. Bauru: EDUSC, 2001.

10. CORREAA, R. L. A dimensão cultural do espaço: alguns temas. Espaço e Cultura, v. 1, n.1, p. 1-22, out. 1995.

11. Campo e Perspectivas da Geografia Cultural. In: . ROSENDHAL, Z. (Orgs.).

Geografia Cultural: Um Século (3). Rio de Janeiro: UERJ, 2002. p. 133-195.

12. . A geografia cultural.3. ed. Florianópolis: UFSC, 2007.

13. . Região cultural: um tema fundamental. In: .; ROSENDAHL, Z. (Orgs.). Espaço e cultura: pluralidade temática. Rio de Janeiro: EdUERJ, 2008. p. 11-43.

14. DEBARBIEUX, B; LARDON, S. (Org.). Les figures du projet territorial. Paris: Auberdatar, 2003.

15. DESCOLA, P.; INGOLD, T. Être au monde: quelle expérience commune? Lyon: Presse universitaire de Lyon, 2014.

16. DIEGUES, A. C; ARRUDA, R. S. V; SILVA, V. C. F; FIGOLS, F. A. B; ANDRADE, D. Os Saberes Tradicionais e a Biodiversidade no Brasil. São Paulo: Ministério do Meio Ambiente, dos Recursos Hídricos e da Amazônia Legal/COBIO-Coordenadoria da Biodiversidade/NUPAUB - Núcleo de Pesquisas sobre Populações Humanas e Áreas Úmidas Brasileiras, 1999. 
17. EMBRAPA. Manual de Métodos de Análise de Solo. 2. ed. Rio de Janeiro: EMBRAPA, 2011.

18. FLORIANI, N. Avaliação das terras pelos agricultores ecológicos de Rio Branco do Sul-PR:uma abordagem geo-socio-agronômica da paisagem rural. 2007.344 f. Tese (Doutorado em Meio Ambiente e Desenvolvimento) - Universidade Federal do Paraná, Curitiba, 2007.

19. ; CARVALHO, S M; STRACHULSKI, J. Saber ecológico tradicional de um território faxinalense: imaginários de fertilidade e práticas da sociobiodiversidade na paisagem das 'terras de plantar.' Geografia, v. 39, n.1, p. 21-39, 2014.

20. GOMES, I. A. Mapeamento preditivo de solos do Faxinal Taquari dos Ribeiros: abordagem pedológica e etnopedológica. 2011, 88 f. Dissertação (Mestrado em Gestão do Território) - Universidade Estadual de Ponta Grossa, Ponta Grossa, 2011.

21. HAESBAERT, R. Região, diversidade territorial e globalização. GEOgraphia, v. 1, n. 1, p. 1539, 1999. Disponível em: <http://www.uff.br/geographia/ojs/index.php/geographia/article/ view/4/3>. Acesso em: 30 de abril de 2016.

22. HAURESKO, C.; MOTECA, G. A pequena propriedade agrária no Paraná Tradicional: origem, localização e caracterização. In: SIMPÓSIO DE PÓS GRADUAÇÃO EM GEOGRAFIA DO ESTADO DE SÃO PAULO, 1., 2008, Rio Claro, SP. Anais... Rio Claro: Unesp, 2008. p. 1076-1093. Disponível em: <http://www.rc.unesp.br/igce/simpgeo/1076-1093cecilia.pdf >. Acesso em: 26 de outubro de 2012.

23. HÉNIN, S.; FÉODOROFF, A.; GRAS, R.; MONNIER, G. Le Profil cultural: principes de physiquedu sol. Paris: Société d'Editions des Ingénieurs Agricoles, 1960.

24. HERNÁNDEZ HERNÁNDEZ, M. El paisaje como seña de identidad territorial: valorización social y factor de desarrollo, ¿utopía o realidad? Boletín de la A.G.E, n. 49, p. 169-183, 2009. Disponível em: $<$ http://www.boletinage.com/articulos/49/09\%20HERNANDEZ.pdf $>$. Acesso em: 2 de julho de 2015.

25. HOLZER, W. Trajeção: reflexões teóricas sobre a paisagem vernacular. In: ROSENDAHL, Z:; CORREAA, R. L. (Orgs.). Espaço e cultura: pluralidade temática. Rio de Janeiro: EDUERJ, 2008. p. 155-172.

26. IPARDES. Diagnóstico socioeconômico do Território Paraná Centro. $1^{\text {a }}$ fase: caracterização global. Curitiba: IPARDES, 2007.

27. JOHNSON, A.W. Individuality and experimentation in agriculture. Human Ecology, v.1, n.2, p.149-159, 1972.

28. LARCHER, W. Ecofisiologia vegetal. São Carlos: Ed. Rima, 2000.

29. LATOUR, B. Jamais fomos modernos: ensaio de antropologia simétrica. 34. ed. Rio de Janeiro: 1994.

30. LEFF, E. Ecologia, capital e cultura: racionalidade ambiental, democracia participativa e desenvolvimento sustentável. Editora da FURB. Blumenau, 2000.

31. MATHIEU, N. Le concept de mode d'habiter à l'épreuve du développement durable. l'Académie d'agriculture de France, v. 4 , n. 96, p. 41-55, 2010. Disponível em: $<$ http://hal-paris1.archivesouvertes.fr/halshs-00732262/fr/>. Acesso em: 28 de abril de 2016.

32. MAZOYER, M.; ROUDART, L. História das agriculturas no mundo: do neolítico à crise contemporânea. São Paulo: UNESP, 2010. 
33. MCDOWELL, L. As transformações da geografia cultural. In: GREGORY, D.; MARTIN, R.; SMITH, G (Orgs.). Geografia humana: sociedade, espaço e ciência social. Rio de Janeiro: Zahar, 1996. p. 159-188.

34. MENDONÇA, F. Geografia socioambiental. Terra Livre, n. 16, p. 113-132, jan./jun. 2001.

35 . La connaissance du climat au Brésil : entre le vernaculaire et le scientifique. Confins, v. 15, p. 5-20, 2012. Disponível em: <https://confins.revues.org/7610>. Acesso em: 26 de abril de 2016.

36. PAULINO, E. T. Terra e vida: a geografia dos camponeses no Norte do Paraná. 2003. 430f. Tese (Doutorado em Geografia) - Universidade Estadual Paulista Júlio de Mesquita Filho.

37. PAVAN, M. A.; BLOCH, M. F.; ZEMPULSKI, H. C.; MIYAZAWA, M.; ZOCOLER, D. C. Manual de análise química de solo e controle de qualidade. Londrina: IAPAR, 1992. (Circular, 76).

38. PORTO-GONÇALVES, C. W. O latifúndio genético e a r-existência indígeno-campesina. Geographia, v. 4, n. 8, p. 30-44, jul./dez. 2002. Disponível em: <http://www.uff.br/geographia/ ojs/index.php/geographia/article/view/86/84>. Acesso em 27 de abril de 2016.

39. . Geografia da riqueza, fome e meio ambiente: pequena contribuição crítica ao atual modelo agrário/agrícola de uso dos recursos naturais. Inter Thesis, v. 1, n. 1, p. 1-55, 2004. Disponível em: <https://periodicos.ufsc.br/index.php/interthesis/article/view/604/10751>. Acesso em: 27 de abril de 2016.

40. PROMIPAC (Programa para el Manejo Integrado de Plagas). Guíasalud de suelos. Tegucigalpa: PROMIPAC/CRS/PRONORCEN/CICUTEC/PASOLAC, 2001. Disponível em: <http://www. share4dev.info/ffsnet/documents/3665.pdf >. Acesso em 13de agosto de2013.

41. RIBAS VILAS, J. Planificación y gestión del paisaje rural. In: BOLÓS, M. (Org.). Manual de ciência del paisaje: teoria, método y aplicaciones. Madrid: Masson, 1992, p. 250-262.

42. RIZZINI, C. T. Tratado de Fitogeografia do Brasil: aspectos ecológicos, sociológicos e florísticos. 2. ed. Rio de Janeiro: Âmbito Cultural Edições Ltda., 1997.

43. SANTOS, H. G.; JACOMINE, P. K. T.; ANJOS, L. H. C.; OLIVEIRA, V. Á.; LUMBRERAS, J. F.; COELHO, M. R.; ALMEIDA, J. A.; CUNHA,T. J. F.; OLIVEIRA, J. B. Sistema Brasileiro de Classificação de Solos. 3. ed. rev. ampl. Brasília: Embrapa, 2013.

44. SANTOS, R. D.; LEMOS, R. C.; SANTOS, H. G.; KER, J. C.; ANJOS, L. H. C. Manual de descrição e coleta de solo no campo. 5. ed. Revisada e ampliada. Viçosa: Sociedade Brasileira de Ciência do Solo, 2005.

45. SEIXAS, C. S. Abordagens e técnicas de pesquisa participativa em gestão de recursos naturais. In: Gestão integrada e participativa de recursos naturais. Conceitos, métodos e experiências. Florianópolis: APED/Secco, 2005, p. 73-105.

46. SILVA, N. R. Etnopedologia e qualidade do solo no assentamento Roseli Nunes, PiraíRJ.2010. 105 f.Dissertação (Mestrado em Agroecossistemas) - Universidade Federal de Santa Catarina. Florianópolis. 2010. Disponível em:<https://repositorio.ufsc.br/bitstream/ handle/123456789/94009/289911.pdf?sequence=1>. Acesso em 25de maio.2013. 
47. STRACHULSKI, J. Abordagem etnoecológica da relação solos-plantas em propriedades do subsistema 'terra de plantar' no Faxinal Taquari dos Ribeiros, Rio Azul - PR. 2011.108 f.Monografia (Graduação em Geografia) - Universidade Estadual de Ponta Grossa, Ponta Grossa. 2011.

48. SUERTEGARAY, D. M. A. Geografia Física e Geomorfologia. Uma (Re)leitura. Ijuí: Ed. Unijuí, 2002.

49. SUERTEGARAY, D. M. Geografia e Interdisciplinaridade. Espaço geográfico: interface natureza e sociedade. Geosul, v. 18, n. 35, p. 43-54, jan./jun. 2003. Disponível em: <http:// www.compassolugarcultura.com/arquivodoc/005.pdf>. Acesso em: 25 de abril de 2016.

50. SUERTEGARAY, D. M. A. Ambiência e pensamento complexo: Resignific(ação) da Geografia. In: SILVA, A. D.; GALENO, A. (Orgs.). Geografia - Ciência do Complexus. Ensaios Transdisciplinares. Curitiba: Ed. Sulina/UFPR, p. 181-208, 2004.

51. TABET, D. Economia agraria e ambiente naturale. Milano: Franco Angeli, 1989.

52. TEIXEIRA, J. C. Modernização da agricultura no Brasil: impactos econômicos, sociais e ambientais. Revista Eletrônica da Associação dos Geógrafos Brasileiros, v. 2, n. 2, p.21-42, 2005. Disponível em: <http://www.ceul.ufms.br/revista-geo/jodenir.pdf>. Acesso em: 15 de outubro de 2012.

53. THRIFT, N. Visando o âmago da região. In: GREGORY, D.; MARTIN, R.; SMITH, G. (Orgs.). Geografia humana: sociedade, espaço e ciência social. Rio de Janeiro: Zahar, 1996. p. 215-247.

54. TOLEDO, V. M. Indigenous knowledge of soil: an ethnoecological conceptualization. In: BARRERA-BASSOLS, N.; ZINK, J. A. (Orgs.). Ethnopedology in a worldwide perspective. Enschede: International Institute for Geo-information and Earth Observation, 2000, p. 1-9.

55. ___ BARRERA-BASSOLS, N. La memoria biocultural: La importancia ecológica de las sabiduríastradicionales. 1. ed. Barcelona: Icaria,2008.

56. .; BARRERA-BASSOLS, N. A etnoecologia: uma ciência pós-normal que estuda as sabedorias tradicionais. Desenvolvimento e Meio Ambiente, n. 20, p. 31- 45, jul./dez. 2009. Disponível em: <http://ojs.c3sl.ufpr.br/ojs2/index.php/made/article/viewFile/14519/10948>. Acesso em: 3 de junho de2010.

57. VALVERDE O. Sistema de roças: agricultura nômade ou itinerante. Revista Portuguesa de Geografia, v. 3, n. 6, p.225-239, 1968. Disponível em: <http://www.ceg.ul.pt/finisterra/ numeros/1968-06/06_07.pdf>. Acesso em: 25 de outubro de 2012.

58. VERDEJO, M. E.. Diagnóstico rural participativo. Brasília, Ministério do Desenvolvimento Agrário. Secretaria da Agricultura Familiar, 2006.

59. VIVEIROS DE CASTRO, E. B. A inconstância da alma selvagem e outros ensaios de Antropologia. São Paulo: Cosac \& amp./Naify, 2002.

60. WAIBEL. L. Princípios da Colonização Européia no Sul do Brasil. Revista Brasileira de Geografia. Ano XI. n. 2. p. 159-222, 1949. Disponível em: <http://biblioteca.ibge.gov.br/visualizacao/periodicos/115/ rbg_1949_v11_n2.pdf >. Acesso em: 25 de abril de 2016. 
61. WALDMAN, M. Meio ambiente e antropologia.São Paulo: Editora Senac São Paulo, 2006.

62. WINKLERPRINS, A. M. G. A., SANDOR, J. A. Local soil knowledge: insight, application, and challenges. Geoderma, v. 111, p. 165-170, 2003. 